\title{
An Overview on Green Synthesis of Nanomaterials and Their Advanced Applications in Sustainable Agriculture
}

Aamir Ali Aslamª, Awais Ali Aslam ${ }^{\text {b }}$, Muhammad Suhail Aslam, Sameer Quazi ${ }^{4}$

1. Institute of Physics, Riphah International University, Lahore, Pakistan. (chemist.awais155@gamil.com)

2. Department of Chemistry, COMSATS University Islamabad, Lahore, Pakistan. (aawais064@gmail.com)

3. Department of Mathematics, University of Lahore, Lahore, Pakistan. (muhammadsuhailaslamrao@gmail.com)

4. GenLab Biosolutions Private Limited, Bangalore, Karnataka, India. (560043)

5. Department of Biomedical Sciences, School of Life Sciences, Anglia Ruskin University, United Kingdom. (colonel.quazi@gmail.com) (sq159@student.aru.ac.uk)

\begin{abstract}
The excess use of unsafe pesticides and mineral fertilizers in agriculture has led to serious health problems and environmental pollution. Nanotechnology has been solving these problems by providing nanoparticles (NPs) with excellent performance. By green synthesis of nanoparticles from plants, animals, and microbes, the use of hazardous and toxic chemicals has become limited. Nanoparticles have excellent performance in many fields such as electronics, cosmetics, automobiles, catalysis, biosensors, bioengineering, etc. NPs also showed excellent performance in agriculture by improving crop production and food quality. Various nano-based agroparticles that have conducted many smart and efficient agricultural systems involving nanopesticides, nanofertilizers, nanoherbicides etc. Apart from enhancing the food production, these materials operate some other functions like as identifying disease in plants, control release of nutrients, delivery of nutrients at target sites, etc. various nanofertilizers such as Fe, Mn, N, K, Mo, P, CNTs and $\mathrm{P}$ showed excellent targeted delivery performance. Nanopesticides and many nanoformulations have showed excellent pest protection performance. Here we reviewed the sources of nanomaterials and their excellent performance in agriculture.
\end{abstract}

Keywords: nanoparticles, nanopesticides, nanofertilizers, nanoherbicides, sustainable agriculture, nanotechnology. 


\section{Contents}

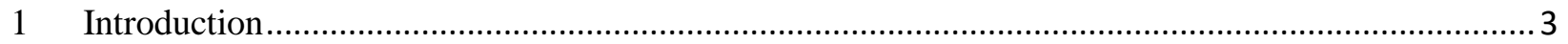

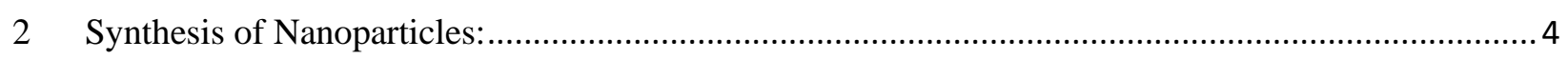

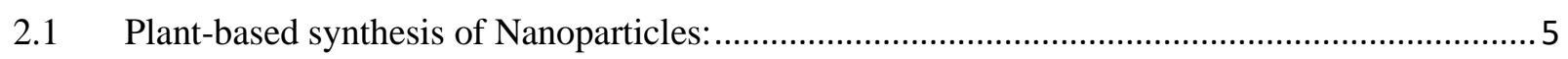

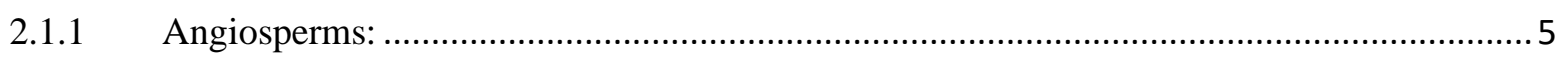

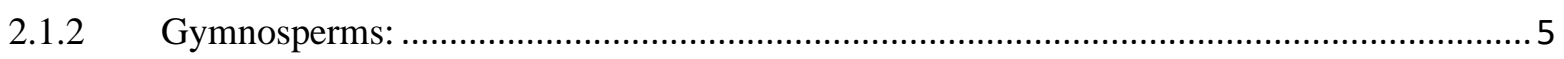

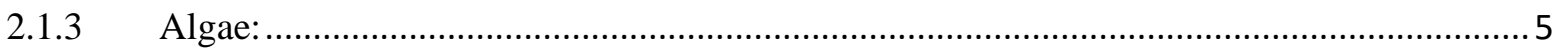

2.2 Green synthesis of Nanoparticles from Animal-derived material:.......................................... 7

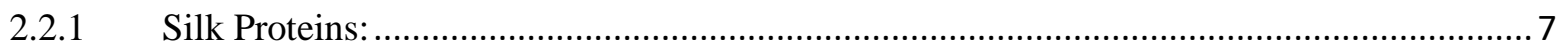

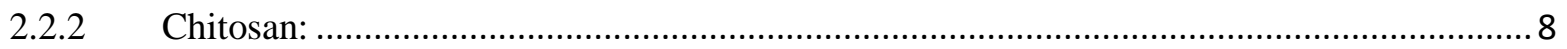

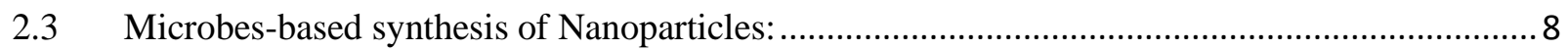

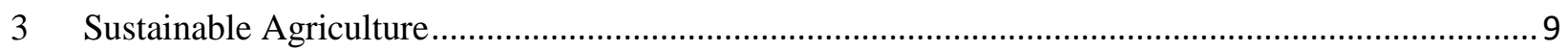

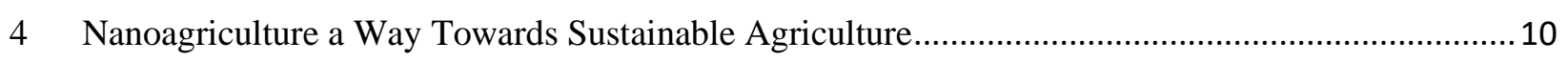

5 Applications of Nanoparticles in Agriculture ....................................................................... 11

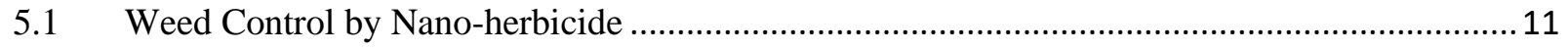

5.1.1 Detoxification of Herbicides Residues...................................................................... 12

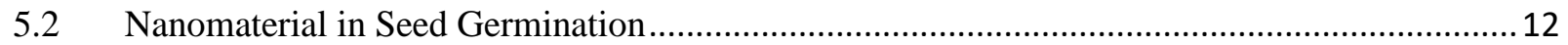

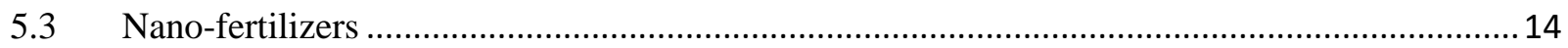

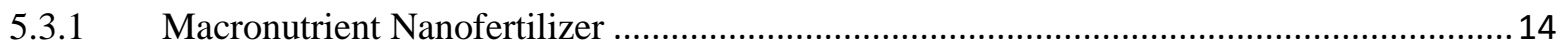

5.3.2 Micronutrient Nanofertilizer ................................................................................ 15

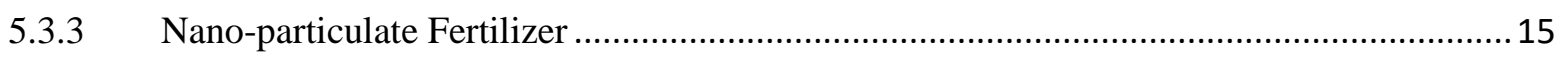

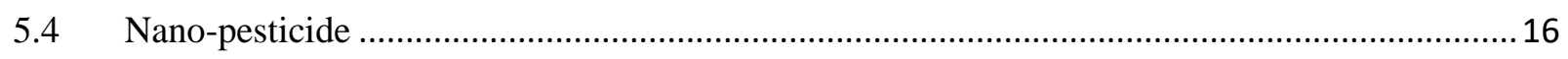

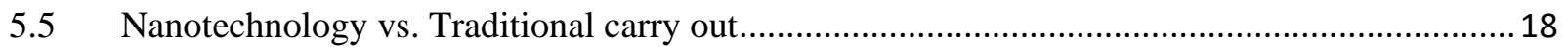

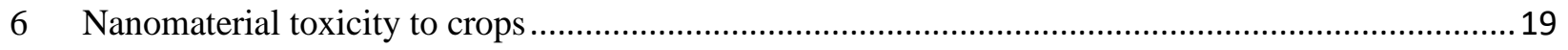

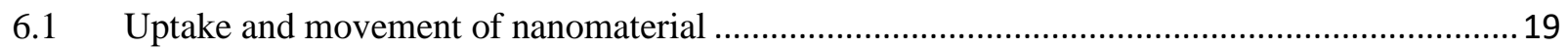

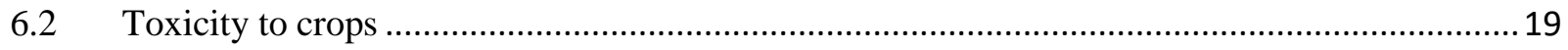

$7 \quad$ Detoxification mechanism in crops induced by nanomaterial ......................................................20

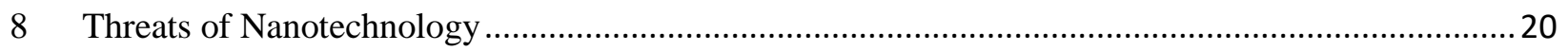

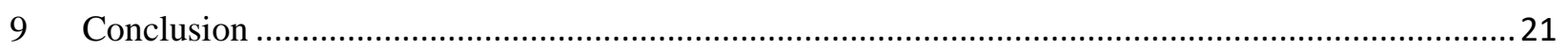

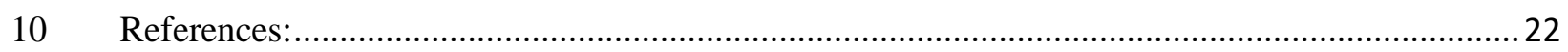




\section{Introduction}

Nanoparticles have dimension in the range of 1 to 100 nanometer and enact as a tie between materials of different magnitude and molecular or atomic entities [1]. They manifest exceptional and miraculous attributes because of their higher reactivities which in turn is due to their large surface areas and smaller sizes [2-4]. Beginning of the nineteenth century has brought the attention of scientists towards the capacity of biological entities to curtail the metal antecedents but the processes are still undetermined. Population explosion, urbanization and speedy industrialization have ended up in the ruin of earth's atmosphere and tremendous amount of unhealthy matter is in air. More knowledge is to be discerned about the secrets of nature and its natural products which would lead to the advancements in the field of nanoparticles' synthesis. Nanoparticles are widely implied in different era of research and most significantly in the field of agriculture. Nanomaterials has mny applications in different fields such as paints, semi-onducting devices, cosmetics, medicines, etc. illustrated in figure 1 . So, such synthesis processes need to be developed that do not utilize toxic reagents. Hence, green synthesis of nanoparticles turns out to be a suitable alternative to physical and chemical methods [5]. Nanoparticles manufactured through biological methods have gained much favor over nanoparticles synthesized from physical or chemical methods. NPs synthesized from physico-chemical methods come out with many problems such as the utilization of toxic reagents and hazardous by-products [6]. Plant based (green) synthesis of nanoparticles is evidently not a hazardous method as metal salt is synthesized by the use of plant extract.

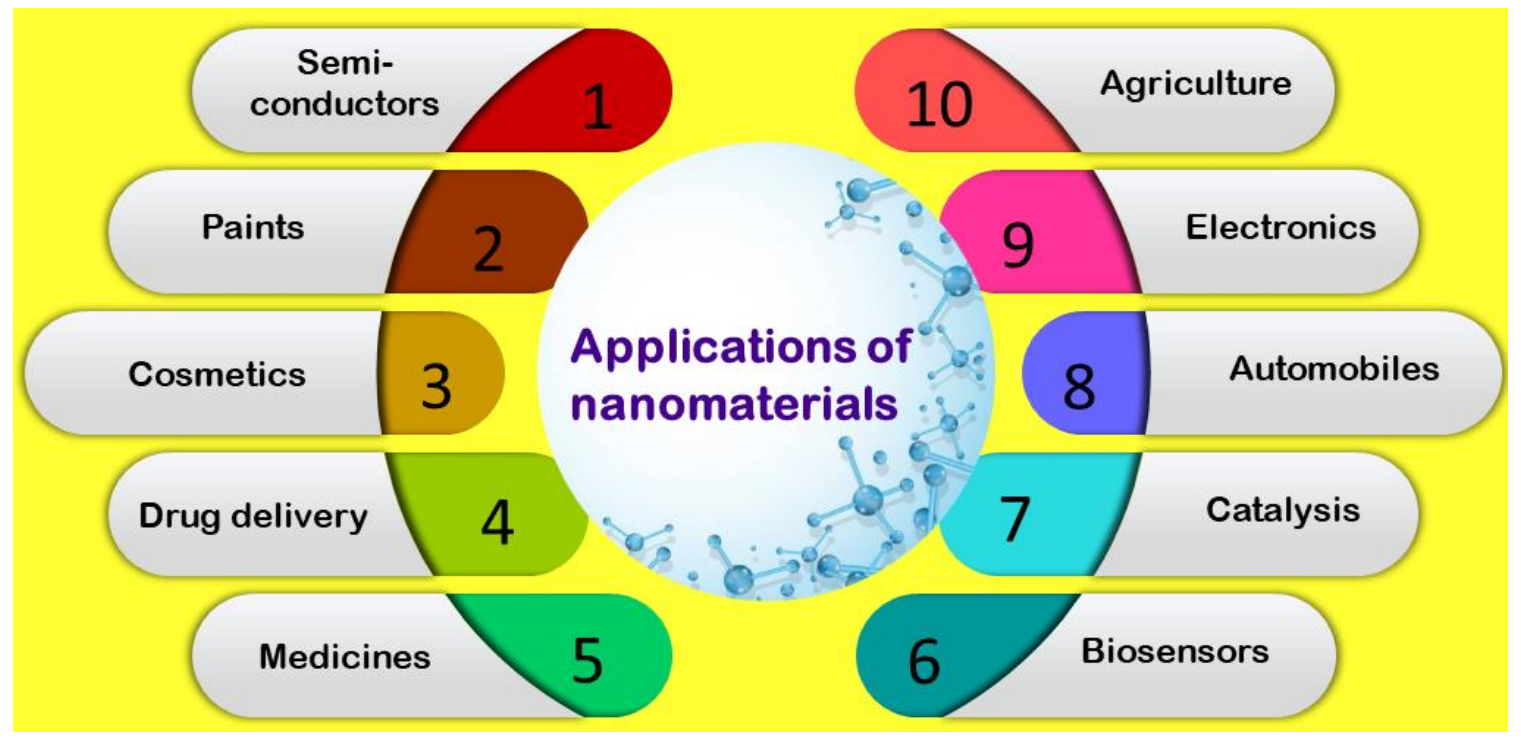

Figure 1. Applications of nanomaterials in different fields.

Green synthesis is the procedure for the development of nanoparticles which makes use of natural resources such as plant extracts, micro-organisms and energy conserving processes in a more economical, non-toxic and sustainable way [7, 8]. Green nano-technology is an energy efficient and safer process. It minimizes wastes production and green-house gas emissions. Renewable material utilization for such products is very beneficial and has lesser environmental impacts in 
terms of energy and pollution and so is termed as eco-friendly. In order to be utilized for specific applications, extracts from different plants are used in the production of NPs with characteristic functionalities. Micro-organisms like bacteria, yeasts, algae and fungi are used. Choice of microorganisms depends on functionalities, size and type of the desired nanoparticles [9]. Green synthesis which utilizes biological molecules from plant extracts has turned out to be of much significance as compared to chemical means as plants are safe, promptly available and diverse which makes it fit for a sustainable bio-resource. The reaction rates for plant mediated synthesis of nanoparticles are higher ranging from few minutes to hours and reaction primarily can take place at room temperature. The exercise of plant extracts to manufacture high quality nanoparticles is in huge practice because of simple steps involved in recovering nanoparticle. The steps are abstraction of plant, extract filtration and metal NP salt addition. Resultant solution is stirred and NPs are eventually recovered from precipitate[7].

Involvement of nanotechnology in agriculture sector has inclined to be a vital factor for sustainable development. It has a great potential to transform the whole agricultural sector with innovative means which enhance the agricultural productivity of plants through adept supplements in the mode of nano-nutrients for nano-fertilizers, nano-pesticide and nano-herbicides by the plants [10]. Nano-materials are utilized for plants' protections as nano-herbicides, nano-pesticides and nanosensors as well. Nano-nutrients or nano-fertilizers have tremendous effects on growth, rate of germination, phytotoxicty of various field crops and vegetables [11].

Nanoparticles being comparable to virus in size may be inhaled by humans and may end up in bloodstream or other sites in the human body like heart, blood cells or liver [12,13]. As toxicity of the NPs depends on origin, many of the NPs may have non-toxic or positive effects on health. Exposure to NPs might have general acute toxic effects which include protein denaturation, generation of reactive oxygen species, perturbations in phagocytic functions and also in mitochondrial disconcertion. Other common and chronic toxic effects of NPs may include neoantigens' generation which results in enlargement or dysfunctioning of the organs [13].

\section{Synthesis of Nanoparticles:}

The biological preparation of Nanoparticles via the green method utilizes the plants and animals to cause the conversion of metallic ions into neutral atoms. Green synthesis (GS) is also done by the elimination of toxic chemicals. Hence, the green synthesized nanoparticles (NPs) offers you the improved biocompatibility in dealing with the biomedical application as compared to the chemically synthesized ones.

There are multiple plant species and groups, among which the Angiosperms and Algae are widely studied. The green-synthesis from the plants-derived materials such as chitin and silk also reported in the past. Different kinds of researches in the past have proved the capability of various plants' specie in green synthesis of nanoparticles and their capping behavior. Not just the plants but the animal-derived biomolecules are also responsible for this. 


\subsection{Plant-based synthesis of Nanoparticles:}

This section will highlight all the signs of progress made towards the green synthesis of nanoparticles via the plant species. Most commonly, the plant species having medicinal applications play a major role in the green synthesis process. Plant-based nanomaterials are listed in table 1 .

\subsubsection{Angiosperms:}

The plant's lineage has the angiosperms at the top and hence these are widely utilized for the green synthesis of NPs. Their easy access, wide applications, availability all over the world have further favored this synthesis. Also, the Angiosperms play an essential role in dealing with human and animal diseases [14]. The nature of Angiosperm plants have aided in processing the natural reducing ability in improving this green domain. The green Synthesis has received many updates in its library especially in the Asian Countries due to enriched plant resources. But not all the plant's species can do justice with the green synthesis of plants.

Most of the researches made on the angiosperm species have revealed that the synthesis of Gold and Silver Nanoparticles is quite common as compared to the other magnetic Nanoparticles. The reason behind this fact is the poor capability of converting the metal cation into lower reduction potential. Various researches have contributed to the plant-based production of nanoparticles. A well-explored plant named Camellia Sinensis has been considered an advantageous plant's specie in GS of NPs. The purification of living molecules present in this plant's species viz. catechins, theaflavins, and their isolation has confirmed their role in green synthesis of Au NPs [15, 16]. Similarly, the pure tea polyphenol is utilized for the synthesis of Pt NPs. Another plant's specie named Jatropha curcas $L$ is responsible for the reduction of metal cations via the cyclic peptide molecules [17]. Therefore, the overall research progress that has been completed recently in this newly-emerged green synthesis domain is quite impressive as compared to the conventional methods.

\subsubsection{Gymnosperms:}

Gymnosperms were the first to have the seeds in plants category, hence they are of much importance. Each group of plants further have distinct metabolites. These metabolites are further responsible for the reduction of metal ions to synthesize the nanoparticles. The studies regarding the green synthesis of NPs from gymnosperms is quite restricted but evident to some extent. Various researches have been made in this sense, and the NPs synthesized from the gymnosperms have different sizes, morphology, and quantity depending on plant type [18-22]. Noruzi et al have synthesized the Au NPs from the Thuja orientalis extract in just a 10-minutes of reaction time. The overall efficiency was found out to be $90 \%$ and the produced Nanoparticles were round in shape and crystalline in nature [23].

\subsubsection{Algae:}

The three main criteria to synthesize and hence achieve the efficiency in the GS of NPs are mainly the reducing agent, stabilizing capping agent, and acceptable solvent [24]. The algae-based 
preparation of nanoparticle is one such process. These are photoautotrophic in nature [25]. Hence, the bio-reduction of algae can synthesize the metal and metal oxide NPs [26-30]. Spirulina platensis is a kind of edible blue-green alga that is utilized to synthesize the gold and silver NPs [31]. Senapati et al. have synthesized the gold NPs via Tetraselmis kochinensis plant [32].

Table 1. List of nanoparticles derived from plants.

\begin{tabular}{|c|c|c|c|}
\hline Plant & Nanoparticle & Size $(\mathbf{n m})$ & Ref. \\
\hline Allium cepa $\mathrm{L}$. & $\mathrm{Au}$ & $\sim 100$ & [33] \\
\hline Allium sativum $\mathrm{L}$. & $\mathrm{Ag}$ & $4.4 \pm 1.5$ & [34] \\
\hline Achyranthus aspera $\mathrm{L}$. & $\mathrm{Ag}$ & $20-30$ & {$[35]$} \\
\hline Anacardium occidentale $\mathrm{L}$. & $\mathrm{Au}$ & - & {$[36]$} \\
\hline Andrographis paniculata Nees. & $\mathrm{Ag}$ & 28 & [37] \\
\hline Astragalus gummifer Labill. & $\mathrm{Ag}$ & $13.1 \pm 1.0$ & [38] \\
\hline Azadirachta indica A. Juss. & $\mathrm{Au}$ & $2-100$ & [39] \\
\hline Camellia sinensis $\mathrm{L}$. & $\mathrm{Au}$ & 25 & [40] \\
\hline Carica papaya $\mathrm{L}$. & $\mathrm{Ag}$ & 15 & [41] \\
\hline Centella asiatica $\mathrm{L}$. & $\mathrm{Ag}$ & - & [42] \\
\hline Chenopodium album $\mathrm{L}$. & $\mathrm{Ag} \mathrm{Au}$ & 12,10 & [43] \\
\hline Coleus aromaticus Lour. & $\mathrm{Ag}$ & $40-50$ & {$[44]$} \\
\hline Cinnamomum zeylanicum Blume. & $\mathrm{Pd}$ & 15 to 20 & {$[45]$} \\
\hline Cinnamoтит camphora $\mathrm{L}$. & $\mathrm{Pd}$ & $3.2-6.0$ & [46] \\
\hline Citrullus colocynthis $\mathrm{L}$. & $\mathrm{Ag}$ & 31 & [47] \\
\hline Datura metel L. & $\mathrm{Ag}$ & $16-40$ & [48] \\
\hline Desmodium triflorum (L) DC. & $\mathrm{Ag}$ & $5-20$ & [49] \\
\hline Diopyros kaki & $\mathrm{Pt}$ & $2-12$ & [50] \\
\hline Dioscorea bulbifera L. & $\mathrm{Ag}$ & $8-20$ & [51] \\
\hline Dioscorea oppositifolia $\mathrm{L}$. & $\mathrm{Ag}$ & 14 & [52] \\
\hline Elettaria cardamomom (L) Maton. & $\mathrm{Ag}$ & - & [53] \\
\hline Gardenia jasminoides Ellis. & $\mathrm{Pd}$ & $3-5$ & {$[54]$} \\
\hline Glycyrrhiza Glabra L. & $\mathrm{Ag}$ & 20 & [55] \\
\hline Hibiscus cannabinus $\mathrm{L}$. & $\mathrm{Ag}$ & 9 & {$[56]$} \\
\hline Hydrilla verticilata (L.f.) Royle. & $\mathrm{Ag}$ & 65.55 & {$[57]$} \\
\hline Jatropha curcas $\mathrm{L}$. & $\mathrm{ZnS}$ & 10 & {$[58]$} \\
\hline Justicia gendarussa $\mathrm{L}$. & $\mathrm{Au}$ & 27 & [59] \\
\hline Lantana camara $\mathrm{L}$. & $\mathrm{Ag}$ & 12.55 & [60] \\
\hline Leonuri herba $\mathrm{L}$. & $\mathrm{Ag}$ & $9.9-13.0$ & {$[61]$} \\
\hline Macrotyloma uniflorum (Lam) Verdc. & $\mathrm{Au}$ & $14-17$ & {$[62]$} \\
\hline Mentha piperita $\mathrm{L}$. & $\mathrm{Ag}, \mathrm{Au}$ & 90,150 & {$[63]$} \\
\hline
\end{tabular}




\begin{tabular}{|c|c|c|c|}
\hline Mirabilis jalapa $\mathrm{L}$. & $\mathrm{Au}$ & 100 & [64] \\
\hline Morinda pubescens $\mathrm{L}$. & $\mathrm{Ag}$ & $25-50$ & [65] \\
\hline Ocimum sanctum $\mathrm{L}$. & $\mathrm{Ag}$ & $4-30$ & [66] \\
\hline Parthenium hysterophorus $\mathrm{L}$. & $\mathrm{Ag}$ & 10 & [67] \\
\hline Pedilanthus tithymaloides (L) Poit. & $\mathrm{Ag}$ & $15-30$ & [68] \\
\hline Piper betle $\mathrm{L}$. & $\mathrm{Ag}$ & 3-37 & [69] \\
\hline Piper nigrum $\mathrm{L}$. & $\mathrm{Ag}$ & $5-50$ & [70] \\
\hline Plumeria rubra $\mathrm{L}$. & $\mathrm{Ag}$ & $32-220$ & [71] \\
\hline Sesuvium portulacastrum $\mathrm{L}$. & $\mathrm{Ag}$ & $5-20$ & [72] \\
\hline Solanum xanthocarpum L. & $\mathrm{Ag}$ & 10 & [73] \\
\hline Sorghum Moench. & $\mathrm{Ag}, \mathrm{Fe}$ & 10,50 & [74] \\
\hline Soybean (Glycine Max) L. & $\mathrm{Pd}$ & $\sim 15$ & [75] \\
\hline Swietenia mahogany (L) Jacq. & $\mathrm{Ag}$ & - & [76] \\
\hline Syzygium aromaticum (L) Merr. \& Perr. & $\mathrm{Au}$ & $5-100$ & [77] \\
\hline Terminalia catappa $\mathrm{L}$. & $\mathrm{Au}$ & $10-35$ & [78] \\
\hline Trianthema decandra $\mathrm{L}$. & $\mathrm{Ag}$ & $10-50$ & [79] \\
\hline Tridax procumbens $\mathrm{L}$. & $\mathrm{CuO} 2$ & - & {$[80]$} \\
\hline Vitus vinifera $\mathrm{L}$. & $\mathrm{Pb}$ & 661 & [81] \\
\hline Zingiber officinale Rosc. & $\mathrm{Ag} \mathrm{Au}$ & 10 & [82] \\
\hline
\end{tabular}

\subsection{Green synthesis of Nanoparticles from Animal-derived material:}

Polymer nanomaterials have their unique and distinct properties depending on their surface area, microbial encumbrance, and the size of pores. Many animals' species either unicellular or multicellular are involved in the synthesis of NPs.

\subsubsection{Silk Proteins:}

Multiple species of insects and spiders made the silk fibroin which is a semi-crystalline polymer containing amino acids like glycine, alanine, and serine. This material is employed in the tissue engineering of bones, skin, muscles, and blood vessels. The basic reason is its non-toxic, less harmful, and non-immunogenic nature. Multiple evidences have been found regarding the green synthesis of nano-composites via the utilization of fibroin. The most common is the fibroin- $\mathrm{TiO}_{2}$ [83] nano-composites and the nano-hydroxyapatite silk fibroin [84]. All the obtained nanocomposites were crystalline in nature and $100 \mathrm{~mm}$ in length. Another component named sericin, which is present in the effluents of silk industries is also responsible for the synthesis of NPs. The nano-sericin powder is obtained via the ultra-sonification which reduces the particle size [85]. 


\subsubsection{Chitosan:}

The invertebrate chitin is responsible for providing you the multiple applications in various fields. For example, the chitosan nano-fibers are perfect to colorize the textiles. Moreover, the medical filed is also benefited from this peptide. It is involved in the slow release of vaccines as well as cancer treatment. Nano-chitosan also plays a noteworthy role in reducing the contamination of environment. Furthermore, Sahab et al have synthesized the PAA NPs of the $50 \mathrm{~nm}$ size which have the anti-fungal uses [86].

The magnetic chitosan plays a major role in removing the organic dyes from the wastewater. The large quantity of hydroxyl as well as amino groups present in chitosan are responsible for a good adsorption rate against the organic dyes when used with the magnetism of $\mathrm{Fe}_{3} \mathrm{O}_{4}$ [87]. Similarly, synthetic dyes can also be removed via the bentonite-chitosan nano-composites [88].

\subsection{Microbes-based synthesis of Nanoparticles:}

There had been a number of techniques and processes employed to obtain the nanoparticles by different precursors $[89,90]$. Some of the techniques were not budget-friendly while some were toxic due to the excessive use of chemicals, while the rest synthesize the NPs via the UV radiation or aerosol spray $[90,91]$. Hence, to minimize all these problems, the microbes-based synthesis of NPs is practiced significantly [91]. The microbes-based synthesis of NPs has now become an interesting research to make and has a bright future ahead as well due to the number of applications $[89,91,92]$.

The nanomaterials are obtained from the microbes via two different methods including the intracellular and extracellular [89, 93]. Their mechanism is different as per the species and NPs you want to obtain. The intracellular mechanism is based on the transfer of positive metal ions through the cell wall which is due to the negative ions already present in the cell wall of bacteria. These ions were then reduced by the specific proteins i.e. enzymes into the NPs. While, in fungi the extracellular mechanism takes place. In this approach, the metal ions are converted to their respective NPs via the nitrate-reductase synthesis method [93]. F.oxysporum produces the silvergold NPs via this extracellular approach when reacts with the Tetrachloroaurate and Silver Nitrate [94]. Also, Aspergillus flavus is involved in the green synthesis of Ag NPs having a size of $8 \mathrm{~nm}$ approximately[95]. Biosynthesis of nanoparticles from microbes is listed in table 2. 
Table 2. Biosynthesis of nanoparticles from microbes.

\begin{tabular}{|l|l|l|l|l|}
\hline Sr. No & Microorganism & Nanoparticle & Size $(\mathbf{n m})$ & Ref. \\
\hline 1 & Lactobacillus sp. & $\mathrm{Ti}$ & $40-60$ & {$[96]$} \\
\hline 2 & P. boryanum UTEX 485 & $\mathrm{Pt}$ & $30-0.3$ & {$[97]$} \\
\hline 3 & Corynebacterium sp. SH09 & $\mathrm{Ag}$ & $10-15$ & {$[98]$} \\
\hline 4 & Desulfovibrio desulfuricans & $\mathrm{Pd}$ & 50 & {$[99]$} \\
\hline 5 & Lactobacillus sp. & $\mathrm{Au}$ & $20-50$ & {$[100]$} \\
\hline 6 & Pseudomonas stutzeri AG259 & $\mathrm{Ag}$ & $<200$ & {$[101]$} \\
\hline 7 & Klebsiella pneumoniae & $\mathrm{CdS}$ & $5-200$ & {$[102]$} \\
\hline 8 & Aquaspirillum magnetotacticum & $\mathrm{Fe}_{3} \mathrm{O}_{4}$ & $40-50$ & {$[103]$} \\
\hline 9 & Bacillus subtilis 168 & $\mathrm{Au}$ & $5-25$ & {$[104]$} \\
\hline 10 & Coriolus versicolor & $\mathrm{Ag}$ & $25-75$ & {$[105]$} \\
\hline 11 & Aspergillus flavus & $\mathrm{Ag}$ & 8.9 & {$[106]$} \\
\hline 12 & V. luteoalbum and isolate 6-3 & $\mathrm{Au}$ & $<10$ & {$[107]$} \\
\hline 13 & F. oxysporum & $\mathrm{BaTiO}$ & 4 & {$[108]$} \\
\hline 14 & F. oxysporum & $\mathrm{Pt}$ & $10-50$ & {$[109]$} \\
\hline 15 & F. oxysporum & $\mathrm{Si}$ & $6-13$ & {$[110]$} \\
\hline 16 & F. oxysporum & $\mathrm{Ti}$ & $5-15$ & {$[110]$} \\
\hline 17 & F. oxysporum & $\mathrm{Au}, \mathrm{Ag}$ & 8,14 & {$[111]$} \\
\hline
\end{tabular}

\section{Sustainable Agriculture}

The idea of sustainable development of agriculture gained immense importance after Brundtlant Report in 1987. Tough its meaning is little vague, United States Department of Agriculture 2012 defined it "agriculture is basically about livestock and production of various crops having impact on environment". The basic concept behind sustainable development of agriculture is to maintain balance between need of food and protecting the environmental resources from declining resources and harmful effects. There are many other aims associated with this sustainable approach like less usage of inorganic fertilizers, protection of water resources, conservation of biodiversity, minimizing waste production etc. [112,113]. Ecofriendly fertilizers have been recognized to increase the crop yield along with better condition of soil [114-117]. To help farmers financially, helping them to implement new techniques and providing them better facilities to upgrade their quality of life is also included in their objectives of sustainable approach[118]. Figure 2 illustrate the different parts of sustainable agriculture. 


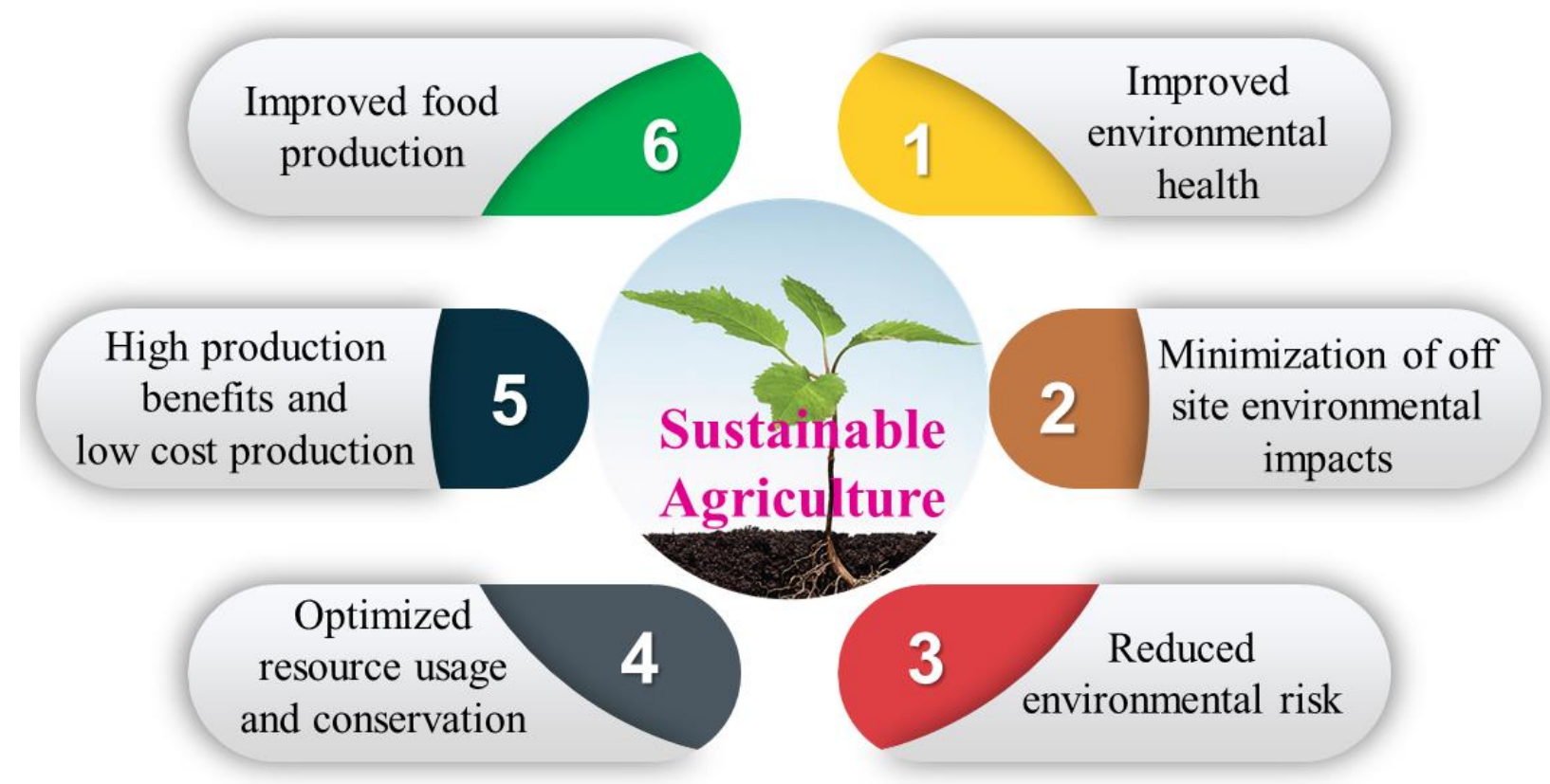

Figure 2. The different parts of sustainable agriculture.

Various farming techniques can be applied to make it better to a certain level. Nanotechnology is one of the progressive and successful techniques to produce highly efficient fertilizers which brings no harm to biodiversity. Agriculture is one of the areas which is totally shifted from conventional techniques to nanotechnology. Use of nano-fertilizers has taken the place of inorganic pesticides because they tend to enhance crop yield and also stimulated sustainable approach widely.

\section{Nanoagriculture a Way Towards Sustainable Agriculture}

Modern agriculture demands sustainable and high crop yield without use of inorganic chemical fertilizers which has adverse effects on health and environment. Hazardous chemicals found in such fertilizers reach under the soil bed via leaching and contaminate water which leads to detrimental outputs. However, preventing measures should be taken to reduce the unwanted and harmful risks produced by chemical fertilizers[119]. Agricultural approach based on nanotechnology is a successful method to obtain attractive yield[120] and production of nanodevices like nanobiosensors(that senses the disease in crops) is a major innovation in the field of agriculture[121]. Other features have been introduced into the nanobiosensors to detect any toxicity caused by microorganisms in plants. Moreover, the very small size of this device make it very easy to use in agricultural lands and fields and these bionanosensors are also used to detect toxicity cause $d$ by fungi [121-123]. Hence, use of nanoparticles in the conventional agriculture system has gained immense importance due to its countless benefits which includes improved quality of soil, smart monitoring, enhanced enzymatic activity, increased nutrients uptake etc. and now this approach is known as nanoagriculture. Figure 3 illustrates the role of nanoparticles in agriculture. 


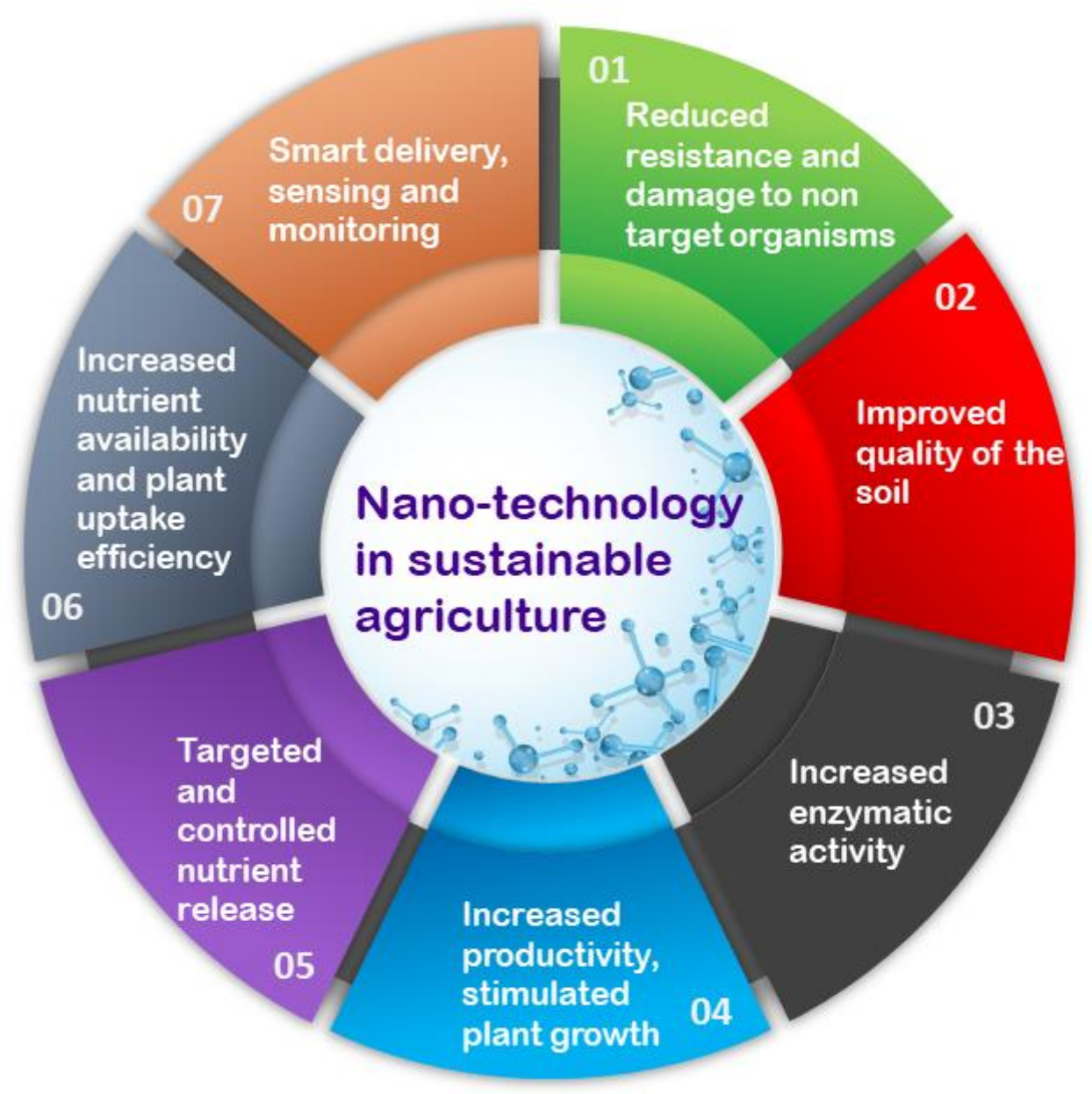

Figure 3. Role of nanoparticles in agriculture.

NPs reduce the nutrient loss thus enhancing the crop production via precise control of nutrients[124, 125]. The present condition of agricultural system is not suitable for better yield but incorporation of nanotechnology with present system would be able to make it better with use of efficient nanodevices and nano-fertilizers considerably[126]. Sustainable methods of agriculture are getting attention recently for its many advantages and environmental friendly nature.

\section{Applications of Nanoparticles in Agriculture}

\subsection{Weed Control by Nano-herbicide}

Herbicide resistance is quite common in the cropped environment due to number of reasons. One most common reason that results in the poor weed control and herbicide resistance is the multispecie approach. Plants can get exposed to one herbicide in one season while a different one in another season. It develops the resistance against the herbicides. Weeds can be controlled by producing an herbicide that attacks the roots of target weeds. Developing this specific herbicide molecule requires the nanoparticle (NP) encapsulation which then enters the roots of weeds to inhibit the glycolysis process. It'll create the starvation condition and particular weed get killed [127]. Applying herbicide in the soil which doesn't have sufficient moisture will lead to 
unfavorable results. Encapsulated herbicide acts by controlled release which takes care of the competing weeds. Moreover, there are adjuvants available for the herbicide. These adjuvants have the nanomaterial employed.

Herbicide paraquat may need a carrier system for action. Silva et al. have prepared the chitosan nanoparticles for this purpose [128]. The characterization of these synthesized nanoparticles was done by the physio-chemical techniques. Next, the process is followed by the evaluation of $\mathrm{pH}$, zeta potential, and size. For this purpose, various techniques have been employed including the TEM, FTIR, and differential Scanning Calorimetry. Therefore, all these techniques were performed to study the release action of 1, 1'-Dimethyl-4, 4'-bipyridinium (Paraquat), an herbicide containing the chitosan NPs. The results depicted that the parquat and herbicide release action is altered via the alginate or chitosan nanoparticles.

\subsubsection{Detoxification of Herbicides Residues}

Crops can sense the damage by the excessive use of herbicides. Whenever herbicides are used in large amounts, the residues can be left behind in the soil. Therefore, using the herbicide over the years will eventually develop the herbicide resistance in the weed growing in that soil and then shift in the weed flora. Broadleaf and grassy weeds have a half-life of nearly 125 days and are also mobile in some soils. These kinds of weeds can be controlled via an herbicide named as Atrazine. This s-triazine-ring herbicide is used globally for this purpose and is now at threat due to residual problems. TNAU, India has raised the hope recently from their study that remediation of residuals of Atrazine is possible within a short time. Silver modified NPs of CMC were applied to remediate the Atrazine residuals from soil and results showed the $88 \%$ success rate of degradation of herbicide [129].

\subsection{Nanomaterial in Seed Germination}

New scientific innovations utilize many approaches and contributed much to the field of nanosciences recently. This situation has been a one step further towards the nanotech applications in agriculture. Nanoscience helped in enhancing the growth of crops, the process of seed germination, and adapting to different environments. Population dynamics and well-being of all the species depends significantly on the seed germination process. Therefore, the germination of seeds is not just a sensitive but important process in the plant's lifecycle. Seed germination, in turn, depends upon multiple factors and attributes i.e. moisture level in soil, nutrients, and soil's compatibility with species [130]. Many studies have been made in this regard and it has been shown that nanomaterials have contributed much to increasing the plant's growth and overall production of crops. It has been depicted that the utilization of Carbon nanotubes (multi-walled) has shown positive effects on the seed development process of soybean, tomato, corn, barley wheat, and more [131-134]. Similarly, nano silicon dioxide $\left(\mathrm{SiO}_{2}\right)$, Titanium Dioxide $\left(\mathrm{TiO}_{2}\right)$, and Zeolite have already influenced the seed germination process in a positive manner for various kinds of crops $[130,135]$. Another research conducted in this regard depicted that the Iron or Silicon Dioxide nanoparticles play an important role in improving the overall seed germination of particular types of crops mainly Barley and Maize [136]. There has been enough evidences now 
concerning the advantageous influences of nanomaterials on seed germination but the actual process behind this is unclear yet. Some studies have reported that after application of nanomaterial, the NPs have the capacity to pass through the seed coat. After passing, they enhance the ability of absorption of water by the seedling. This way, the seedling is better able to grow and germinate under favorable conditions.

Quality enhancement and increase in the crop's yield is also described by employing multiple kinds of nanomaterials. Such nanomaterials include Zinc oxide, Titanium dioxide, carbon nanotubes, Iron Oxide, and $\mathrm{ZnFeCu}$-Oxide [137-139]. Similarly, studies have stated the benefits of the crop growth of $\mathrm{OH}$-functionalized fullerenes via the utilization of carbon nanotubes. Gao et al. studied the growth of hypocotyl in fullerenes in Arabidopsis via the cell division [140]. Therefore, Fullerol has been found responsible for the enhancement in fruit's growth, size, and the overall yield as well. The increase found out to be $128 \%$ and also it cause an increase in the production of bioactive compounds. These bioactive compounds include the Amarine, $\psi, \psi-$ Carotene, charantin, and Chicory Extract [141]. Yousefzadeh and Sabaghnia described that the nano-iron fertilizer enhanced the essential oil contents of plants[142]. In the same way, the nanozinc and boron fertilizers are employed for improving the fruit yield and quality. It includes the process of decreasing the total soluble solids by $4.4-7.6 \%$, an increase in the titratable acidity by $9.5-29.1 \%$, and $0.28-0.62 \mathrm{pH}$ increase in the pomegranate [143]. These evidences are enough to prove the role of nanomaterials in increasing the crop's production and quality. However, the mechanism by which the nanomaterials enhance the growth and quality of plants is still unknown. Some evidences have been found that the nanomaterials increase the intake of nutrients and water and nutrients to improve the root system via increases enzyme activity [137, 138]. Moreover, the studies have also revealed the phenomenon of control or slow release of nanofertilizers in water or soil which helps in availability of nutrients for all the time during cultivation of crops. This availability of nutrients helps to improve the seed sprouting, development, blossoming/flowering, and more [144]. Like, a urea fertilizer (nano-coated in this case) named as hydroxyapatite release the nitrogen contents needed for plant growth at a very slow rate. It releases these contents continuously for 60 days. On the other hand, the traditional fertilizer will end up in 30 days and that too with an unbalanced release. It'll adversely affect the plant's growth and quality of production [145]. In a study, Zheng et al [146] researched about the photosynthesis in spinach. They found out that when $\mathrm{TiO}_{2}$ nanofertilizer is applied, the photosynthesis rate increases by $3.13 \%$ but decreased beyond the $4 \%$. Similarly, Disfani et al [136] made a research on the size of barley and maize seedlings and depicted that the application of nanomaterial i.e. nano $\mathrm{Fe} / \mathrm{SiO}_{2}$ caused an increase in length by approx. $8.3 \%$ and $21 \%$ respectively. But the shoot length have a negative impact on reaching the concentration level above $0.025 \mathrm{~g} / \mathrm{kg}$. This means that the growth of crops depend on the nanomaterials. El Feky et al. [147] suggested that the crop's development and quality also depends upon the application of nanomaterials. The foliar applications of nano $\mathrm{Fe}_{3} \mathrm{O}_{4}$ can increase the total production of chlorophyll, carbohydrate and essential oils content, height, shoot and branches length, and many other factors in Ocimum basilicum plants. 


\subsection{Nano-fertilizers}

These are regarded as the nanomaterials which are capable enough to provide nutrients and certain elements to the plants which are needed for their growth and production [148]. Nanofertilizers are categorized as subject to the type of nutrients plants need. Various nanofertilzers are listed in table 3 .

\subsubsection{Macronutrient Nanofertilizer}

As mentioned in the name, this fertilizer is for the soil where nutrients are obligatory in the large amount, especially for the traditional framing. Macronutrients such as Nitrogen, Phosphorus, Sulphur, Magnesium, Potassium, and Calcium are needed for proper growth. Demands for the production of food are increasing continuously which tends to increase the need for nanofertilizer to 263 MT by 2050 [149]. Nanomaterial has a high volume-to-surface ratio. This brings the utmost efficiency to the applications of macronutrient fertilizer rather than the traditional ones. Therefore, many researchers are working continuously to improve the macronutrients fertilizer to use it at the field scale. In this regard, Liu et al. [148] and Ditta et al. [150] have studied the applications of nanoparticle-based fertilizer. Controlled release of Nitrogen has been achieved by the zeolite chips (Urea coated) and urea-modified hydroxyapatite nanoparticles [145, 151]. Similarly, Liu and Lal [152] have researched on the Calcium and Phosphorus hydroxyapatite nanoparticles which showed an increase of approx. 20.5\% and 34\% in the Glycine max seed yield. Liu et al. [153] have noticed a 15\% increase in the biomass of Arachis hypogeae by the application of Ca NP as compared to the conventional Calcium macronutrient. Moreover, Delfani et al. [154] studied the seed weight of Vigna unguiculata. They found the enhancement by $7 \%$ in the seed weigh after the application of synthesized Mg NP. The effects of nanofertilizers on plant and soil is illustrated in figure 4 .

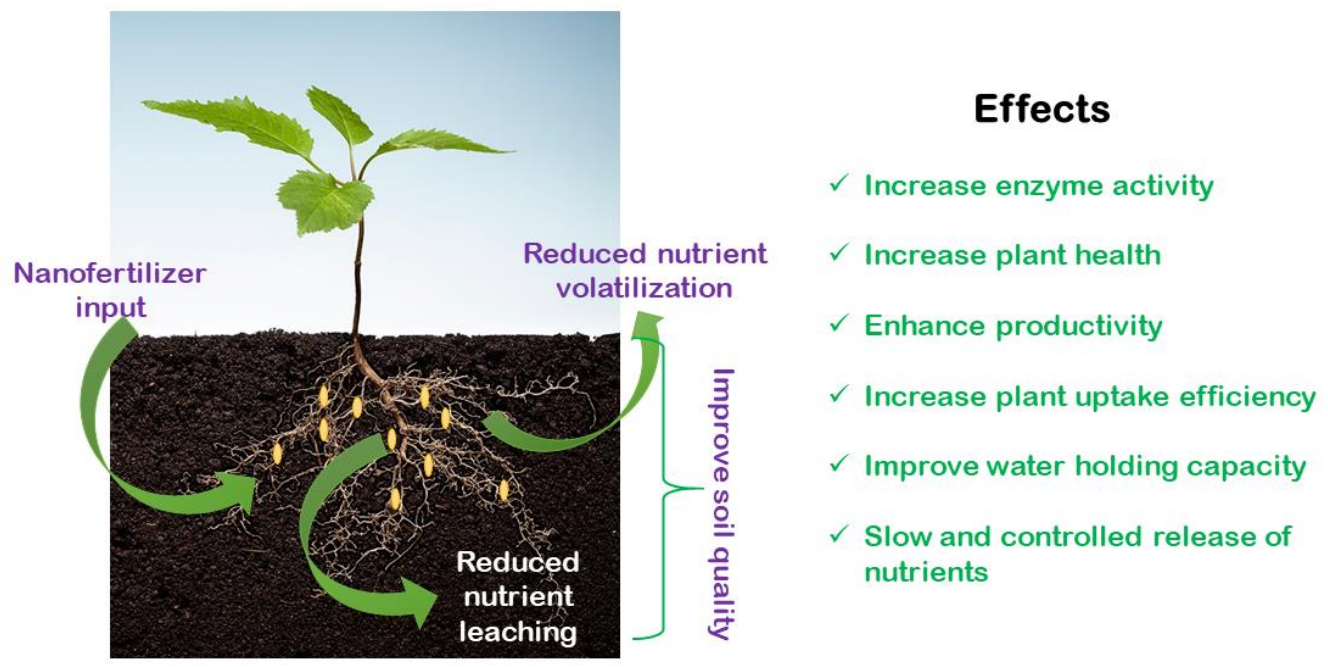

Figure 4. The effects of nanofertilizers on plant and soil. 


\subsubsection{Micronutrient Nanofertilizer}

Though micronutrients are required in smaller quantities but necessary for the metabolic process. The bioavailability to the plants is significantly improved in the case of micronutrients and hence enhances the growth and quality of crops. Delfani et al. [154] have made another research on the chlorophyll contents of black-eyed pea after the application of Fe NP which is improved by $10 \%$. Similarly, Ghafariyan et al. [155] have found out 30-60 ppm concentration increase in the chlorophyll content in G. max. Using bulk Manganese Sulfate will not provide sufficient increase in growth and quality. Therefore, spraying the Mn NP will enhance the biomass by 37-38\%, root length by $52-53 \%$, and shoot length by $38-39 \%$.

Zinc element is responsible to carry out the regulatory mechanism for all the enzyme activities in plants. Zinc Oxide NPs are responsible to enhance or upsurge the contents of biomass, shoot length, root length, and overall growth by improving the protein content. These improvements can be seen in the Vigna Radiate, Cucumis sativas, Raphanus sativus, Brassica napus, and Cluster bean [156-159]. Molybdenum NPs when used in combination with the nitrogen fixation bacteria tend to improve the overall seed growth in chickpea [160].

\subsubsection{Nano-particulate Fertilizer}

Nanoparticles including the Titanium Dioxide, Silicon Dioxide, and carbon nanotubes are significantly responsible to increase the plant's growth and quality of crops. A mixture of Titanium Dioxide, Silicon Dioxide NPs have been seen to improve the seed growth and germination process along with an enhancement in nitrogen fixation in G. $\max$ [135]. Only the Titanium Dioxide NPs have the ability to improve the chlorophyll, protein, and nitrogen content of the Spinacia oleracea [161]. Carbon Nanotubes have been widely used as the fertilizer for diverse species of plants and vegetables. Carbon nanotubes follow the same principle as the nanoparticles and penetrate the seed coat to enhance the water uptake resulting in better growth [162]. 
Table 3. Various nanofertilizers are used in agriculture and their impact on crops.

\begin{tabular}{|c|c|c|c|c|c|}
\hline $\begin{array}{l}\text { Sr. } \\
\text { No }\end{array}$ & Plant & $\begin{array}{l}\text { Nano- } \\
\text { fertilizer }\end{array}$ & $\begin{array}{l}\text { Amount of } \\
\text { nano- } \\
\text { fertilizer } \\
\text { (PPM) }\end{array}$ & Highlights of the study & Ref. \\
\hline 1 & Pennisetum glaucum & $\mathrm{Au}$ & 50 & $\begin{array}{l}\text { Seedling growth and seed } \\
\text { germination }\end{array}$ & {$[163]$} \\
\hline 2 & Arachis hypogaea & $\mathrm{Ca}$ & - & $\begin{array}{l}\text { Plant growth and nutrient } \\
\text { contents }\end{array}$ & {$[164]$} \\
\hline 3 & Cucumis sativus & $\mathrm{CeO}_{2}$ & 400 & $\begin{array}{l}\text { Globuline content and food } \\
\text { quality }\end{array}$ & {$[165]$} \\
\hline 4 & Phoenix dactylifera & CNTs & $0.05-0.1$ & Leaf number and shoot length & {$[166]$} \\
\hline 5 & Lactuca sativa & $\mathrm{Cu}$ & $130-600$ & $\begin{array}{l}\text { Shoot length, germination of } \\
\text { seeds and effect on soil } \\
\text { microbe community }\end{array}$ & {$[167]$} \\
\hline 6 & Zea mays & $\mathrm{CuO}$ & 10 & Plant growth and roots & {$[168]$} \\
\hline 7 & Glycine $\max$ & $\mathrm{FeO}$ & $30-60$ & Effects of NPs on chlorophyll & {$[169]$} \\
\hline 8 & Pisum sativum & $\mathrm{FeO}$ & $250-500$ & Increased chlorophyll & {$[170]$} \\
\hline 9 & Vigna unguiculata & $\mathrm{Mg}$ & 2.5 & Increased chlorophyll & {$[170]$} \\
\hline 10 & Vigna radiata & $\mathrm{Mn}$ & $0.05-1$ & Increased chlorophyll & {$[171]$} \\
\hline 11 & Oryza sativa & $\mathrm{Mn}$ & - & Zn uptake improved & {$[172]$} \\
\hline 12 & Cicer arietinum & Mo & 8 & Increased plant mas & {$[173]$} \\
\hline 13 & Glycine $\max$ & $\mathrm{P}$ & 100 & Growth rate increased & {$[174]$} \\
\hline 14 & Spinacia oleracea & $\mathrm{TiO}_{2}$ & $0.25-4$ & $\mathrm{~N}_{2}$ fixation improved & {$[175]$} \\
\hline 15 & Lolium & $\mathrm{Zn}$ & $1-2000$ & Root elongation & {$[176]$} \\
\hline 16 & Vigna radiata & $\mathrm{ZnO}$ & $1-2000$ & Growth rate increased & {$[177]$} \\
\hline
\end{tabular}

\subsection{Nano-pesticide}

The pesticide industry has an ongoing demand for nanoformulation. In this process, the nanoformulation of traditional pesticide with polymers or metal NPs have advantageous factors to consider. In this regard, the nanoencapsulation of pesticides makes sure the slow release of the ingredients over a prolonged time. This way, you can also reduce the run-off of pesticides [178, 179]. Nanocarriers have a similar advantage of site-specific delivery. Another method named as 
nanoemulsion is getting thoughts of professionals [180]. In this method, the nanoemulsion process can enhance the overall solubility and absorbing capacity of pesticides in soil. The impact of nano pesticides on plants is explained in table 4.

Table 4. Impact on nanopesticides on plants.

\begin{tabular}{|c|c|c|c|c|}
\hline Nanoparticles & Pathogen & Plant disease & Effect & Ref. \\
\hline $\mathrm{Ag}$ & $\begin{array}{l}\text { Xanthomonas } \\
\text { campestris } \\
\text { pv.campestris }\end{array}$ & Bacterial blight & $\begin{array}{l}\text { Improved bacterial } \\
\text { reduction }\end{array}$ & {$[181]$} \\
\hline $\begin{array}{l}\text { Ag } \quad \text { core- } \\
\text { DHPAC shell }\end{array}$ & $\begin{array}{l}\text { Phytophthora } \\
\text { nicotianae }\end{array}$ & Fungal disease & Growth inhibition & [182] \\
\hline $\mathrm{FeO}$ & F. oxysporum & Fungal disease & Growth inhibition & [183] \\
\hline \multirow[t]{2}{*}{ Chitosan } & $\begin{array}{l}\text { Colletotrichum } \\
\text { capsici }\end{array}$ & Diseases in chilli & $\begin{array}{l}\text { Reduce mycelia growth } \\
\text { rate }\end{array}$ & [184] \\
\hline & $\begin{array}{l}\text { Macrophomina } \\
\text { phaseolina }\end{array}$ & Fungal disease & $\begin{array}{ll}\text { Stopped } & \text { spore } \\
\text { germination } & \end{array}$ & {$[185]$} \\
\hline \multirow[t]{3}{*}{$\mathrm{Cu}$} & Fusarium sp & Fungal disease & Antifungal & [186] \\
\hline & $\begin{array}{l}\text { Phytophthora } \\
\text { infestans }\end{array}$ & Disease in tomato & Antifungal & {$[187]$} \\
\hline & $\begin{array}{l}\text { Xanthomonas } \\
\text { axonopodis } \\
\text { punicae }\end{array}$ & Bacterial blight & $\begin{array}{l}\text { Improved bacterial } \\
\text { growth inhibition }\end{array}$ & [188] \\
\hline $\begin{array}{l}\text { Silver-GO } \\
\text { composite }\end{array}$ & $\begin{array}{l}\text { Xanthomonas } \\
\text { performance }\end{array}$ & Bacterial Spots & $\begin{array}{l}\text { Improved bacterial } \\
\text { growth inhibition }\end{array}$ & [189] \\
\hline
\end{tabular}

Silver NPs are one of the nanopesticides which is active against the number of pests in a diverse range of plants including Botrytis cinerea, Colletotrichum, Phoma, and more. Similarly, a combination of Silica and Silver NPs has been proven utmost effective against the powdery mildew [190-193]. Cu nanoparticles are also proven effective against the gram-positive and negative bacteria in low concentration. These NPs were also used against the fungal disease pathogens including Fusarium sp., Phytophtora infestance and more [194]. The impact of nanoformulation based materials on pest control are listed in table 5. 
Table 5. Impact of nanoformulation based materials on pest control.

\begin{tabular}{|c|c|c|c|c|c|}
\hline $\begin{array}{l}\text { Nano- } \\
\text { formulations }\end{array}$ & Pesticides & Pathogen & $\begin{array}{l}\text { Plant } \\
\text { disease }\end{array}$ & Effect & Ref. \\
\hline $\begin{array}{l}\text { Porous hollow } \\
\text { silica }\end{array}$ & Validamycin & - & - & $\begin{array}{l}36 \% \text { loading capacity } \\
\text { increased }\end{array}$ & {$[195]$} \\
\hline $\begin{array}{l}\text { Cellulose/silica } \\
\text { nanocomposites }\end{array}$ & Tebuconazole & $\begin{array}{l}\text { Moulds and } \\
\text { rust }\end{array}$ & Leaf decay & Enhanced release rate & [196] \\
\hline $\mathrm{CaCO}_{3}$ & Validamycin & $\begin{array}{l}\text { Rhizoctonia } \\
\text { solani }\end{array}$ & - & Controlled release & [197] \\
\hline Lignin & Diuron & - & - & Controlled release & [198] \\
\hline $\mathrm{TiO}_{2}$ & $\begin{array}{l}\text { With } \mathrm{Ag} \text { and } \\
\mathrm{Zn}\end{array}$ & $\begin{array}{l}\text { Xanthomonas } \\
\text { perforans }\end{array}$ & $\begin{array}{l}\text { Disease in } \\
\text { tomato }\end{array}$ & $\begin{array}{l}\text { Improved bacterial } \\
\text { reduction }\end{array}$ & [199] \\
\hline
\end{tabular}

$\mathrm{Zn}$ NPs is another in the category which was proven effective as nano fertilizer but also as an antifungal agent. These NPs were used and found effective against the Penicillium expansum, $B$. cinerea, Apergillus flavus and more [200, 201]. Zinc Oxide NPs have another benefit of being less harmful against the silver NPs. Before making these methods of nanomaterial application to the crops and plants commercial, the control action should be practiced. The Nano-pesticide act must be structured by the centralized organizations in this regard.

\subsection{Nanotechnology vs. Traditional carry out}

Target framing is getting common these days in nano-agriculture field in which nanoparticles are applied to increase the growth and crop eminence [202, 203]. In terms of seed development or germination and plant growth promotion, the CNTBs (carbon nanotubes) have replaced all other traditional methods [146, 204]. Cu bactericides were used in the past which is now replaced by the nanosized bacteriophages. Their smaller size along with the greater surface to volume ratio makes them more proficient as compared to all other traditional practices. A comparison of nanomaterials and conventional materials is illustrated in figure 5. NPs work in a manner by penetration through the apoplast and then into the epidermal and cortical layers. They accumulate inside as an aggregation [158, 205]. Similarly, Rico et al. [206] studied another penetration pathway i.e. symplastic, and found out as more organized and regulated. 


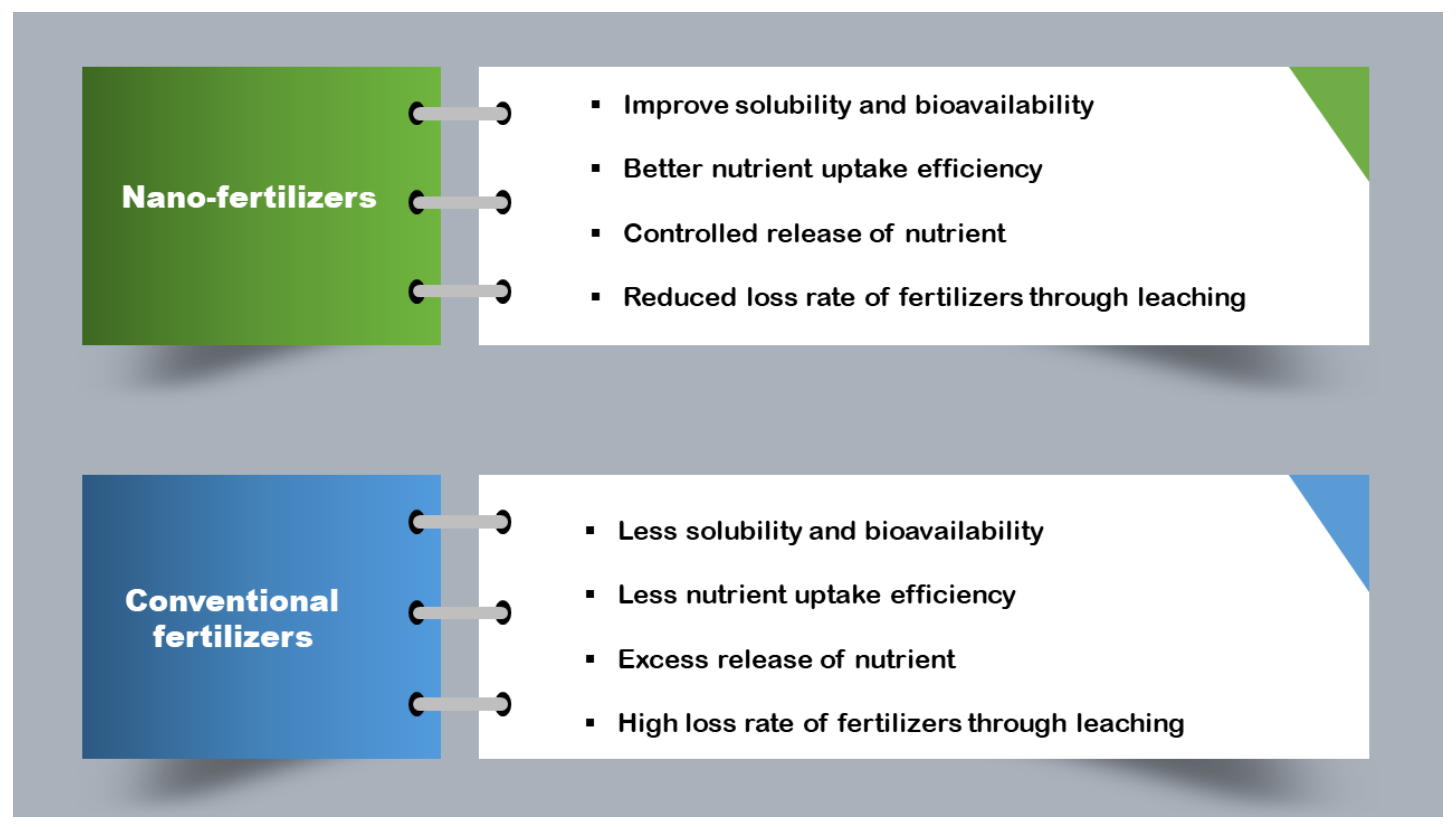

Figure 5. A comparison of nanomaterials and conventional materials.

\section{Nanomaterial toxicity to crops}

\subsection{Uptake and movement of nanomaterial}

Nanoparticles play a vital role in the study of how a plant responds to different aspects like size, height, and uptake of NPs, and 40-50 nm absorption is observed in the literature[207, 208]. Moreover, coating materials also contribute significantly to the absorption and uptake of nanoparticles. Different species of plants require different quantities of nanoparticles to absorb in a specific time and concentration is provided[208]. A plant can take up nanoparticles via symplastic movement or apoplastic or both[209-211]. Symplastic movement is a result of endocytosis and occurs when nanoparticles cross the outer membrane[212]. NPs are taken up by the plant and reach out to several parts of plants it could be edible like fruits or non-edible like stem, leaf, and roots[213, 214].

\subsection{Toxicity to crops}

Nanoparticles can cause harm to plants in both direct and indirect ways. The high exposure of NPs to plants may adversely affect the growth of roots and leaves and the process of germination as well.[215, 216]. The most harmful biochemical reactions of nanoparticles include the production of reactive oxygen species in higher amount which affects uptake and movement of water in plants, cause OS(oxidative stress) and problems in photosynthesis and other chemical reactions[217, 218]. Many genetic changes were observed in the response to using various nanoparticles on $\mathrm{N}$. Tabacam and A. cepain. The toxicity of titanium oxide nanoparticles was compared with copper oxide NPs and cadmium oxide NPs [219, 220].

It was concluded that $\mathrm{TiO}_{2} \mathrm{NPs}$ are the least toxic among them and $\mathrm{CuO}_{2} \mathrm{NPs}$ cause high damage to DNA with the formation of $8 \mathrm{OH}_{2}$ 'dG. Hong et al studied that exposure of $\mathrm{nCeO}_{2}$ over Cucumis Stivus causes changes in the enzymatic behavior of plants [216]. Damage to chloroplast, 
destruction of vascular bundle, and variation in uptake of nutrients occur when nan- ceria is applied is provided to cotton plants [221].

\section{Detoxification mechanism in crops induced by nanomaterial}

Formation of reactive oxygen species (ROS) is an important harmful mechanism of NPs which badly affects the normal functioning of crops. Nanoparticles are very small in size and have higher activity due to large surface areas which results in higher induction of reactive oxygen species by NPs. Prevention from damages and in the regulation of ROS antioxidants (both enzymatic and non-enzymatic) plays a vital role.

Major antioxidant enzymes are peroxides, SODs, and CAT and GSH and phenolics are the chief non-enzymatic antioxidants. Use of nanoparticles causes changes in the behavior of antioxidants. It has been revealed by studies that exposure of Ag NPs with R.Communis results in higher production of reactive oxygen species[222]. The toxic effect of Ag NPs in A.thaliana is a disturbance in water levels and photosynthesis(by effecting chlorophyll content badly)[223].

Exposure of $\mathrm{CuO}$ NPs on A.thaliana revealed that toxicity is caused by the release of copper ions [224]. Servin et al. reported that exposure of tin oxide NPs on cucumber cause induction of catalases but no APX activity[214]. The effect of $\mathrm{Nd}(\mathrm{III})$ oxide NPs in pumpkin cause higher activities of peroxidase and superoxide dismutases but decreases in the activity of catalases and APX (Chen et al. 2016). Rico et al. studied that use of nanoceria in rice has adverse effects on GSH resulting destruction of membranes and photosynthesis. Servin described that upon exposure of tin oxide NPs(250-750mg L-1) cause an increase in catalases activity but no effect on APX activity[214].

\section{Threats of Nanotechnology}

The higher growth rate of nanoparticles production and its applications in various areas are well known[225]. The present level of usage and mixing of nanoparticles is not harmful but it cannot be ignored that there is a chance in increasing the concentration of NPs in the coming years[226, 227].

Nanotechnology has its own merits and demerits [228]. NPs can be obtained directly (via natural sources) or indirectly (via anthropogenic production). Nanoparticles are present in soil via rain or supply through agricultural activities. The concentration of NPs is high in the soil as compared to water and air, due to slow movement in soil NPs continue to stay there for a longer period of time[229]. Nano-fertilizers are major source of nanoparticles contamination because plants uptake NPs present in soil and NPs move through the plant and reach to various parts of plants and ultimately to human when human consumes the product of that plant. The adverse effects of NPs include a higher rate of reactive oxygen species, chromosomal aberration, genetic defects, and cause harm to different organs in humans. There are many sites of entry for nanoparticles into the human body. They can enter via breathing, eating, and even by injecting during the medical processes. The major issue is the activities and responsibilities of NPs inside the human body like how nanoparticles behave with tissues and different organs[228]. Chances of cytotoxicity 
increases when a high concentration of nanoparticles are used. During the past few decades, nanoparticles are being produced on a very large scale and they end up causing toxicity in the environment. Researchers revealed that Ag NPs are used in the making of socks because they help to lessen smell but they affect adversely when released in the wash[230]. Ag NPs are bacteriostatic they may destroy other bacteria which are helpful for the degradation of organic material in waste treatment farms. By knowing the threats of NPs, authorities such as EPA(environmental protection agency) and FDA(food \& drug administration) have started taking preventing measures to reduce the risks produced by NPs[228].

\section{Conclusion}

As the need for food grows rapidly, it is important to enhance the productivity of crops. Regarding to improved crop production, it is important to find an advanced solution that can accelerate productivity and not pollute the environment. The integration of nanotechnology in agriculture has provided the final solution needed for the development of the agricultural sector. Nanoparticles modify conventional agricultural particles as they target, control the release of chemicals that are not harmful to soil microorganisms, and unmarked organisms, including crop plants, and ultimately they are not natural. As nano fertilizers release nutrients slowly and consistently, they also reduce the high cost of continuous application of fertilizers. Furthermore, nano fertilizers are highly capable of controlling the environmental pressure of the soil and the active ingredients as required. Although these unique properties of nano-based agricultural particles have made them a viable candidate, nanotechnology is still in its infancy in agriculture. A detailed study of the ecological pathways of these advanced organisms is not yet known and is being explored. When their adverse effects on ecosystems are fully understood and their long-term effects are well explored, the full potential of nanoparticles can be utilized.

\section{Declarations.}

- Acknowledgements: None

- Availability of Data and Materials: N/A

- Conflict of Interest: None

- Funding: None

- Informed Consent: N/A

- Research involvement of Human or animals: N/A 


\section{References:}

1. Thakkar, K., S. Mhatre, and R. Parikh, Biological synthesis of metallic nanoparticles. Nanomed Nanotechnol Biol Med 6:257-262. Nanomedicine : nanotechnology, biology, and medicine, 2009. 6: p. 257-62.

2. Bogunia-Kubik, K. and M. Sugisaka, From molecular biology to nanotechnology and nanomedicine. Biosystems, 2002. 65(2-3): p. 123-38.

3. Daniel, M.-C. and D. Astruc, Gold Nanoparticles: Assembly, Supramolecular Chemistry, Quantum-Size-Related Properties, and Applications toward Biology, Catalysis, and Nanotechnology. Chemical Reviews, 2004. 104(1): p. 293-346.

4. Zharov, V.P., et al., Self-assembling nanoclusters in living systems: application for integrated photothermal nanodiagnostics and nanotherapy. Nanomedicine, 2005. 1(4): p. 326-45.

5. Singh, A., et al., Plant-nanoparticle interaction: An approach to improve agricultural practices and plant productivity. International Journal of Pharmaceutical Science Invention (IJPSI), 2015. 4: p. 2319-6718.

6. Li, X., et al., Biosynthesis of Nanoparticles by Microorganisms and Their Applications. Journal of Nanomaterials, 2011. 2011: p. 270974.

7. Ahmed, S., et al., A review on plants extract mediated synthesis of silver nanoparticles for antimicrobial applications: A green expertise. Journal of Advanced Research, 2016. 7(1): p. 17-28.

8. Rastogi, L. and J. Arunachalam, Sunlight based irradiation strategy for rapid green synthesis of highly stable silver nanoparticles using aqueous garlic (Allium sativum) extract and their antibacterial potential. Materials Chemistry and Physics, 2011. 129(1): p. 558-563.

9. Azmath, P., et al., Mycosynthesis of silver nanoparticles bearing antibacterial activity. Saudi Pharmaceutical Journal, 2016. 24(2): p. 140-146.

10. Tarafdar, J., S. Shikha, and R. Raliya, Nanotechnology: Interdisciplinary science of applications. African Journal of Biotechnology, 2013. 12: p. 219-226.

11. Shalaby, T., et al., Nanoparticles, Soils, Plants and Sustainable Agriculture. 2016.

12. Buzea, C., I.I. Pacheco, and K. Robbie, Nanomaterials and nanoparticles: Sources and toxicity. Biointerphases, 2007. 2(4): p. MR17-MR71.

13. Gnach, A., et al., Upconverting nanoparticles: assessing the toxicity. Chemical Society Reviews, 2015. 44(6): p. 1561-1584.

14. Petrovska, B.B.J.P.r., Historical review of medicinal plants' usage. 2012. 6(11): p. 1.

15. Nune, S.K., et al., Green nanotechnology from tea: phytochemicals in tea as building blocks for production of biocompatible gold nanoparticles. 2009. 19(19): p. 2912-2920.

16. Alshatwi, A.A., J. Athinarayanan, and P.V.J.J.o.M.S.M.i.M. Subbarayan, Green synthesis of platinum nanoparticles that induce cell death and G2/M-phase cell cycle arrest in human cervical cancer cells. 2015. 26(1): p. 7.

17. Joglekar, S., et al., Novel route for rapid biosynthesis of lead nanoparticles using aqueous extract of Jatropha curcas L. latex. 2011. 65(19-20): p. 3170-3172.

18. Iravani, S. and B.J.B.r.i. Zolfaghari, Green synthesis of silver nanoparticles using Pinus eldarica bark extract. 2013. 2013.

19. Velmurugan, P., et al., Pine cone-mediated green synthesis of silver nanoparticles and their antibacterial activity against agricultural pathogens. 2013. 97(1): p. 361-368. 
20. Coccia, F., et al., One-pot synthesis of lignin-stabilised platinum and palladium nanoparticles and their catalytic behaviour in oxidation and reduction reactions. 2012. 14(4): p. 1073-1078.

21. Song, J.Y., B.S.J.B. Kim, and b. engineering, Rapid biological synthesis of silver nanoparticles using plant leaf extracts. 2009. 32(1): p. 79.

22. Arundoss, T., et al., ARTICLE INFO ABSTRACT. 2013. 4(10): p. 140-144.

23. Noruzi, M., et al., A rapid biosynthesis route for the preparation of gold nanoparticles by aqueous extract of cypress leaves at room temperature. 2012. 94: p. 84-88.

24. Sau, T.K. and C.J.J.J.o.t.A.C.S. Murphy, Room temperature, high-yield synthesis of multiple shapes of gold nanoparticles in aqueous solution. 2004. 126(28): p. 8648-8649.

25. Castro, L., et al., Biological synthesis of metallic nanoparticles using algae. 2013. 7(3): p. 109-116.

26. Azizi, S., et al., Green biosynthesis and characterization of zinc oxide nanoparticles using brown marine macroalga Sargassum muticum aqueous extract. 2014. 116: p. 275-277.

27. Jena, J., et al., Biosynthesis and characterization of silver nanoparticles using microalga Chlorococcum humicola and its antibacterial activity. 2013. 3(1): p. 1-8.

28. Lengke, M.F., M.E. Fleet, and G.J.L. Southam, Synthesis of platinum nanoparticles by reaction of filamentous cyanobacteria with platinum (IV)- chloride complex. 2006. 22(17): p. 7318-7323.

29. Momeni, S., I.J.A.b. Nabipour, and biotechnology, A simple green synthesis of palladium nanoparticles with Sargassum alga and their electrocatalytic activities towards hydrogen peroxide. 2015. 176(7): p. 1937-1949.

30. MubarakAli, D., et al., Synthesis and characterization of CdS nanoparticles using Cphycoerythrin from the marine cyanobacteria. 2012. 74: p. 8-11.

31. Govindaraju, K., et al., Extracellular synthesis of silver nanoparticles by a marine alga, Sargassum wightii Grevilli and their antibacterial effects. 2009. 9(9): p. 5497-5501.

32. Senapati, S., et al., Intracellular synthesis of gold nanoparticles using alga Tetraselmis kochinensis. 2012. 79: p. 116-118.

33. Parida, U., B.K. Bindhani, and P. Nayak, Green Synthesis and Characterization of Gold Nanoparticles Using Onion (Allium cepa) Extract. World Journal of Nano Science and Engineering, 2011. 01.

34. Von White, G., et al., Green Synthesis of Robust, Biocompatible Silver Nanoparticles Using Garlic Extract. Journal of Nanomaterials, 2012. 2012: p. 730746.

35. Daniel, K., et al., Green synthesis and transfer of silver nanoparticles in a food chain through Chiranamous Larva to zebra fish - a new approach for therapeutics. International Journal of Nanoscience and Nanotechnology, 2011. 2: p. 159-169.

36. Sheny, D.S., J. Mathew, and D. Philip, Phytosynthesis of Au, Ag and Au-Ag bimetallic nanoparticles using aqueous extract and dried leaf of Anacardium occidentale. Spectrochim Acta A Mol Biomol Spectrosc, 2011. 79(1): p. 254-62.

37. Sulochana, S., P. Krishnamoorthy, and K. Sivaranjani, Synthesis of silver nanoparticles using leaf extract of Andrographis paniculata. J Pharmacol Toxicol, 2012. 7(5): p. 251258.

38. Kora, A.J. and J. Arunachalam, Green Fabrication of Silver Nanoparticles by Gum Tragacanth (<i>Astragalus gummifer $</ i>$ ): A Dual Functional Reductant and Stabilizer. Journal of Nanomaterials, 2012. 2012: p. 869765. 
39. Thirumurugan, A., Biotechnological synthesis of gold nanoparticles of Azadirachta indica leaf extract. International journal of Biological Technology, 2010.

40. Boruah, S., et al., Green synthesis of gold nanoparticles using Camellia sinensis and kinetics of the reaction. Adv Mater Lett, 2012. 3.

41. Jain, D., et al., Synthesis of Plant-Mediated Silver Nanoparticles using Papaya Fruit Extract and Evaluation of their Anti Microbial Activities. Digest Journal of Nanomaterials and Biostructures, 2009. 4: p. 557-563.

42. Palaniselvam, K., A. Velanganni, and S. Govindan, Karthi, Leaf assisted bioreduction of silver ions using leaves of Centella asiatica L. its bioactivity. . E-journal of life scie, 2012. 1: p. 46-49.

43. Dwivedi, A. and K. Gopal, Plant-Mediated Biosynthesis of Silver and Gold Nanoparticles. Journal of biomedical nanotechnology, 2011. 7: p. 163-4.

44. Vanaja, M. and G. Annadurai, Coleus aromaticus leaf extract mediated synthesis of silver nanoparticles and its bactericidal activity. Applied Nanoscience, 2013. 3(3): p. 217-223.

45. Sathishkumar, M., et al., Phyto-crystallization of palladium through reduction process using Cinnamom zeylanicum bark extract. J Hazard Mater, 2009. 171(1-3): p. 400-4.

46. Yang, X., et al., Green synthesis of palladium nanoparticles using broth of Cinnamomum camphora leaf. Journal of Nanoparticle Research, 2010. 12(5): p. 1589-1598.

47. Satyavani, K., T. Ramanathan, and S. Gurudeeban, Plant mediated synthesis of biomedical silver nanoparticles by using leaf extract of Citrullus colocynthis. Research journal of nanoscience nanotechnology, 2011. 1(2): p. 95-101.

48. Kesharwani, J., et al., Phytofabrication of Silver Nanoparticles by Leaf Extract of Datura metel: Hypothetical Mechanism Involved in Synthesis. Journal of Bionanoscience, 2009. 3: p. 39-44.

49. Ahmad, N., et al., Biosynthesis of Silver Nanoparticles from Desmodium triflorum: A Novel Approach Towards Weed Utilization. Biotechnology Research International, 2011. 2011: p. 454090.

50. Song, J.Y., E.-Y. Kwon, and B.S. Kim, Biological synthesis of platinum nanoparticles using Diopyros kaki leaf extract. Bioprocess and Biosystems Engineering, 2009. 33(1): p. 159.

51. Ghosh, S., et al., Synthesis of silver nanoparticles using Dioscorea bulbifera tuber extract and evaluation of its synergistic potential in combination with antimicrobial agents. Int $\mathbf{J}$ Nanomedicine, 2012. 7: p. 483-96.

52. Maheswari, R.U., Green Synthesis of Silver Nanoparticles by Using Rhizome Extract of Dioscorea oppositifolia L. and their anti microbial activity against Human pathogens. IOSR Journal of Pharmacy and Biological Sciences, 2012. 1: p. 38-42.

53. GnanaJobitha, G., G. Annadurai, and C. Kannan, Green synthesis of silver nanoparticle using Elettaria cardamomom and assesment of its antimicrobial activity. Int. J. Pharma Sci. Res., 2012. 3: p. 323-330.

54. Jia, L., et al., The biosynthesis of palladium nanoparticles by antioxidants in Gardenia jasminoides Ellis: long lifetime nanocatalysts for p-nitrotoluene hydrogenation. Nanotechnology, 2009. 20(38): p. 385601.

55. Dinesh, S., S. Karthikeyan, and P. Arumugam, Biosynthesis of silver nanoparticles from glycyrrhiza glabra root extract. Journal of Applied Science and Research, 2012. 4: p. 178187. 
56. Bindhu, M.R. and M. Umadevi, Synthesis of monodispersed silver nanoparticles using Hibiscus cannabinus leaf extract and its antimicrobial activity. Spectrochimica Acta Part A: Molecular and Biomolecular Spectroscopy, 2013. 101: p. 184-190.

57. Sable, N., et al., Phytofabrication of silver nanoparticles by using aquatic plant Hydrilla verticilata. Nusantara Bioscience, 2012. 4: p. 2087-3948.

58. Hudlikar, M., et al., Latex-mediated synthesis of ZnS nanoparticles: green synthesis approach. Journal of Nanoparticle Research, 2012. 14(5): p. 865.

59. Fazaludeen, M.F., et al., Synthesis and characterizations of gold nanoparticles by Justicia gendarussa Burm F leaf extract. 2012. 2012: p. 23-34.

60. Pandian, S., C. Nethradevi, and S. Renganathan, Synthesis of silver nanoparticles using Lantana camara fruit extract and its effect on pathogens. Asian Journal of Pharmaceutical and Clinical Research, 2012. 5: p. 97-101.

61. Im, A.R., et al., Enhanced antibacterial activities of leonuri herba extracts containing silver nanoparticles. Phytother Res, 2012. 26(8): p. 1249-55.

62. Aromal, S.A., V.K. Vidhu, and D. Philip, Green synthesis of well-dispersed gold nanoparticles using Macrotyloma uniflorum. Spectrochimica Acta Part A: Molecular and Biomolecular Spectroscopy, 2012. 85(1): p. 99-104.

63. MubarakAli, D., et al., Plant extract mediated synthesis of silver and gold nanoparticles and its antibacterial activity against clinically isolated pathogens. Colloids Surf B Biointerfaces, 2011. 85(2): p. 360-5.

64. Vankar, P.S. and D. Bajpai, Preparation of gold nanoparticles from Mirabilis jalapa flowers. Indian J Biochem Biophys, 2010. 47(3): p. 157-60.

65. Mary, E. and L. Inbathamizh, Green synthesis and characterization of nano silver using leaf extract of morinda pubescens. Asian J. Pharm. Clin. Res, 2012. 5: p. 159-162.

66. Ramteke, C., et al., Synthesis of Silver Nanoparticles from the Aqueous Extract of Leaves of $\langle i\rangle$ Ocimum sanctum $</ i\rangle$ for Enhanced Antibacterial Activity. Journal of Chemistry, 2013. 2013: p. 278925.

67. kumar, D.A., RAPID AND GREEN SYNTHESIS OF SILVER NANOPARTICLES USING THE LEAF EXTRACTS OF PARTHENIUM HYSTEROPHORUS: A NOVEL BIOLOGICAL APPROACH. International Research Journal of Pharmacy, 2012.

68. C. Sundaravadivelan, D. and M. Nalini, Biolarvicidal effect of phyto-synthesized silver nanoparticles using Pedilanthus tithymaloides (L.) Poit stem extract against the dengue vector Aedes aegypti L. (Diptera; Culicidae). Asian Pacific J Trop Biomed, 2012: p. 1-8.

69. Koduru, M., et al., Phytofabrication and Characterization of Silver Nanoparticles from Piper betle Broth. Journal of Nanoscience and Nanotechnology, 2012. 2: p. 17.

70. Garg, S., Rapid biogenic synthesis of silver nanoparticles using black pepper (Piper nigrum) corn extract. International Journal of Innovations in Biological and Chemical Sciences, 2012. Vol. 3: p. 5-10.

71. Patil, C.D., et al., Larvicidal activity of silver nanoparticles synthesized using Plumeria rubra plant latex against Aedes aegypti and Anopheles stephensi. Parasitol Res, 2012. 110(5): p. 1815-22.

72. Nabikhan, A., et al., Synthesis of antimicrobial silver nanoparticles by callus and leaf extracts from saltmarsh plant, Sesuvium portulacastrum L. Colloids and Surfaces B: Biointerfaces, 2010. 79(2): p. 488-493. 
73. Amin, M., et al., Green synthesis of silver nanoparticles through reduction with Solanum xanthocarpum L. berry extract: characterization, antimicrobial and urease inhibitory activities against Helicobacter pylori. Int J Mol Sci, 2012. 13(8): p. 9923-41.

74. Njagi, E.C., et al., Biosynthesis of Iron and Silver Nanoparticles at Room Temperature Using Aqueous Sorghum Bran Extracts. Langmuir, 2011. 27(1): p. 264-271.

75. Petla, R.K., et al., Soybean ( Glycine Max ) Leaf Extract Based Green Synthesis of Palladium Nanoparticles. Journal of Biomaterials and Nanobiotechnology, 2012. 03.

76. Mondal, S., et al., Biogenic synthesis of Ag, Au and bimetallic Au/Ag alloy nanoparticles using aqueous extract of mahogany (Swietenia mahogani JACQ.) leaves. Colloids and Surfaces B: Biointerfaces, 2011. 82(2): p. 497-504.

77. Raghunandan, D., et al., Rapid biosynthesis of irregular shaped gold nanoparticles from macerated aqueous extracellular dried clove buds (Syzygium aromaticum) solution. Colloids and Surfaces B: Biointerfaces, 2010. 79(1): p. 235-240.

78. Ankamwar, B., Biosynthesis of Gold Nanoparticles (Green-gold) Using Leaf Extract of $<i>$ Terminalia Catappa </ $i>$. E-Journal of Chemistry, 2010. 7: p. 745120.

79. Geethalakshmi, R. and S. Dvl, Synthesis of plant-mediated silver nanoparticles using Trianthema decandra extract and evaluation of their anti microbial activities. Int. J. Eng. Sci. Technol., 2010. 2.

80. Gopalakrishnan, K., et al., Antibacterial activity of $\mathrm{Cu} 2 \mathrm{O}$ nanoparticles on E Coli synthesized from Tridax Procumbens leaf extract and surface coating with polyaniline. Digest Journal of Nanomaterials and Biostructures, 2012. 7: p. 833-839.

81. Pavani, K., et al., Phytofabrication of lead nanoparticles using Grape skin extract. International Journal of Engineering Science Technology, 2012. 4(7).

82. Singh, C., et al., A green biogenic approach for synthesis of gold and silver nanoparticles using Zingiber officinale. Digest Journal of Nanomaterials and Biostructures, 0002. 6: p. 535-542.

83. Feng, X.-X., et al., Preparation and characterization of novel nanocomposite films formed from silk fibroin and nano-TiO2. 2007. 40(2): p. 105-111.

84. Wang, G., et al., Preparation of nano silk fibroin/hydroxyapatite biological composite by “one-step"'method. 2008. 6: p. 027.

85. Agrawal, P. and S.J.I.J.o.S.R. Bhushan, Preparation of sericin nano particles from waste of silk industry. 2013. 1(3): p. 116-120.

86. Sahab, A., et al., Synthesis, antifungal and insecticidal potential of Chitosan (CS)-g-poly (acrylic acid)(PAA) nanoparticles against some seed borne fungi and insects of soybean. 2015. 8(2): p. 589-598.

87. Sheshmani, S., A. Ashori, and S.J.I.j.o.b.m. Hasanzadeh, Removal of Acid Orange 7 from aqueous solution using magnetic graphene/chitosan: a promising nano-adsorbent. 2014. 68: p. 218-224.

88. Bhattacharyya, R. and S.K.J.A.c.s. Ray, Micro-and nano-sized bentonite filled composite superabsorbents of chitosan and acrylic copolymer for removal of synthetic dyes from water. 2014. 101: p. 510-520.

89. Mandal, D., et al., The use of microorganisms for the formation of metal nanoparticles and their application. 2006. 69(5): p. 485-492.

90. Thakkar, K.N., et al., Biological synthesis of metallic nanoparticles. 2010. 6(2): p. 257262. 
91. Narayanan, K.B., N.J.A.i.c. Sakthivel, and i. science, Biological synthesis of metal nanoparticles by microbes. 2010. 156(1-2): p. 1-13.

92. Mohanpuria, P., N.K. Rana, and S.K.J.J.o.n.r. Yadav, Biosynthesis of nanoparticles: technological concepts and future applications. 2008. 10(3): p. 507-517.

93. Hulkoti, N.I., T.J.C. Taranath, and S.B. Biointerfaces, Biosynthesis of nanoparticles using microbes-a review. 2014. 121: p. 474-483.

94. Senapati, S., et al., Extracellular biosynthesis of bimetallic Au-Ag alloy nanoparticles. 2005. 1(5): p. 517-520.

95. Vigneshwaran, N., et al., Biological synthesis of silver nanoparticles using the fungus Aspergillus flavus. 2007. 61(6): p. 1413-1418.

96. Prasad, K., A.K. Jha, and A.R. Kulkarni, Lactobacillus assisted synthesis of titanium nanoparticles. Nanoscale Research Letters, 2007. 2(5): p. 248.

97. Lengke, M.F., M.E. Fleet, and G. Southam, Synthesis of Platinum Nanoparticles by Reaction of Filamentous Cyanobacteria with Platinum(IV)-Chloride Complex. Langmuir, 2006. 22(17): p. 7318-7323.

98. Zhang, H., et al., Biosorption and bioreduction of diamine silver complex by Corynebacterium. 2005. 80(3): p. 285-290.

99. Yong, P., et al., Bioreduction and biocrystallization of palladium by Desulfovibrio desulfuricans NCIMB 8307. Biotechnology and bioengineering, 2002. 80: p. 369-79.

100. Nair, B. and T. Pradeep, Coalescence of Nanoclusters and Formation of Submicron Crystallites Assisted by Lactobacillus Strains. Crystal Growth \& Design, 2002. 2(4): p. 293-298.

101. Joerger, R., T. Klaus, and C. Granqvist, Biologically Produced Silver-Carbon Composite Materials for Optically Functional Thin-Film Coatings. Advanced Materials, 2000. 12: p. 407-409.

102. Smith, P.R., et al., Photophysical and photochemical characterisation of bacterial semiconductor cadmium sulfide particles. Journal of the Chemical Society, Faraday Transactions, 1998. 94(9): p. 1235-1241.

103. Mann, S., R.B. Frankel, and R.P. Blakemore, Structure, morphology and crystal growth of bacterial magnetite. Nature, 1984. 310(5976): p. 405-407.

104. Beveridge, T.J. and R.G. Murray, Sites of metal deposition in the cell wall of Bacillus subtilis. J Bacteriol, 1980. 141(2): p. 876-87.

105. Sanghi, R. and P. Verma, Biomimetic synthesis and characterisation of protein capped silver nanoparticles. Bioresource Technology, 2009. 100(1): p. 501-504.

106. Vigneshwaran, N., et al., Biological synthesis of silver nanoparticles using the fungus Aspergillus flavus. Materials Letters, 2007. 61(6): p. 1413-1418.

107. Thakkar, K.N., S.S. Mhatre, and R.Y. Parikh, Biological synthesis of metallic nanoparticles. Nanomedicine: Nanotechnology, Biology and Medicine, 2010. 6(2): p. 257262.

108. Bansal, V., et al., Room-Temperature Biosynthesis of Ferroelectric Barium Titanate Nanoparticles. Journal of the American Chemical Society, 2006. 128(36): p. 11958-11963.

109. Riddin, T.L., M. Gericke, and C.G. Whiteley, Analysis of the inter- and extracellular formation of platinum nanoparticles by Fusarium oxysporum $f$. sp. lycopersici using response surface methodology. Nanotechnology, 2006. 17(14): p. 3482-9.

110. Bansal, V., et al., Fungus-mediated biosynthesis of silica and titania particles. Journal of Materials Chemistry, 2005. 15(26): p. 2583-2589. 
111. Senapati, S., et al., Extracellular biosynthesis of bimetallic Au-Ag alloy nanoparticles. Small, 2005. 1(5): p. 517-20.

112. Mahmoud, A.W.M. and S.S. Taha, Main sulphur content in essential oil of Eruca Sativa as affected by nano iron and nano zinc mixed with organic manure. Agriculture (Pol'nohospodárstvo), 2018. 64(2): p. 65-79.

113. Velten, S., et al., What is sustainable agriculture? A systematic review. Sustainability, 2015. 7(6): p. 7833-7865.

114. Singh, R., et al., Sustained nutrient supply, reduced nutrient loss and high plant productivity with slow release fertilizers. Stable food production and sustainable agriculture: a challenge ahead in 21st Century, 2010: p. 62-79.

115. Kumar, M., et al., Increase in growth, productivity and nutritional status of rice (Oryza sativa L. cv. Basmati) and enrichment in soil fertility applied with an organic matrix entrapped urea. Journal of Crop Science and Biotechnology, 2012. 15(2): p. 137-144.

116. Kumar, M., et al., Enhancing Efficacy of Azotobactor and Bacillus by Entrapping in Organic Matrix for Rice Cultivation. Agroecology and Sustainable Food Systems, 2015. 39(8): p. 907-923.

117. Rai, A., et al., Improvement in growth and alkaloid content of Rauwolfia serpentina on application of organic matrix entrapped biofertilizers (Azotobacter chroococcum, Azospirillum brasilense and Pseudomonas putida). Journal of Plant Nutrition, 2017. 40(16): p. 2237-2247.

118. Campbell, B.M., et al., Sustainable intensification: What is its role in climate smart agriculture? Current Opinion in Environmental Sustainability, 2014. 8: p. 39-43.

119. Kah, M., Nanopesticides and nanofertilizers: emerging contaminants or opportunities for risk mitigation? Frontiers in chemistry, 2015. 3: p. 64.

120. Liu, R. and R. Lal, Potentials of engineered nanoparticles as fertilizers for increasing agronomic productions. Science of the total environment, 2015. 514: p. 131-139.

121. Fraceto, L.F., et al., Nanotechnology in agriculture: which innovation potential does it have? Frontiers in Environmental Science, 2016. 4: p. 20.

122. Viswanathan, S. and J. Radecki, Nanomaterials in electrochemical biosensors for food analysis-a review. Polish journal of food and nutrition sciences, 2008. 58(2).

123. Sertova, N.M., Application of nanotechnology in detection of mycotoxins and in agricultural sector. Journal of Central European Agriculture, 2015.

124. Sekhon, B.S., Nanotechnology in agri-food production: an overview. Nanotechnology, science and applications, 2014. 7: p. 31.

125. Wilson, M.A., et al., Nanomaterials in soils. Geoderma, 2008. 146(1-2): p. 291-302.

126. Prasad, R., A. Bhattacharyya, and Q.D. Nguyen, Nanotechnology in sustainable agriculture: recent developments, challenges, and perspectives. Frontiers in microbiology, 2017. 8: p. 1014.

127. Chinnamuthu, C. and E.J.A.o.n.i.a. Kokiladevi, Weed management through nanoherbicides. 2007. 10: p. 978-981.

128. dos Santos Silva, M., et al., Paraquat-loaded alginate/chitosan nanoparticles: preparation, characterization and soil sorption studies. 2011. 190(1-3): p. 366-374.

129. Susha, V., C. Chinnamuthu, and K. Pandian. Remediation of herbicide atrazine through metal nano particle. in International Conference on Magnetic Materials and their Applications in the 21st Century. 2008. 
130. Manjaiah, K.M., et al., Clay minerals and zeolites for environmentally sustainable agriculture, in Modified Clay and Zeolite Nanocomposite Materials. 2019, Elsevier. p. 309-329.

131. Lahiani, M.H., et al., Impact of carbon nanotube exposure to seeds of valuable crops. 2013. 5(16): p. 7965-7973.

132. Anita, S. and D.J.E.C.B. Rao, Enhancement of seed germination and plant growth of wheat, maize, peanut and garlic using multiwalled carbon nanotubes. 2014. 3(5): p. 502504.

133. Khodakovskaya, M.V. and A.S. Biris, Method of using carbon nanotubes to affect seed germination and plant growth. 2020, Google Patents.

134. Joshi, A., et al., Multi-walled carbon nanotubes applied through seed-priming influence early germination, root hair, growth and yield of bread wheat (Triticum aestivum L.). 2018. 98(8): p. 3148-3160.

135. Changmei, L., et al., Research of the effect of nanometer materials on germination and growth enhancement of Glycine max and its mechanism. 2002. 21(3): p. 168-171.

136. Najafi Disfani, M., et al., Effects of nano Fe/SiO2 fertilizers on germination and growth of barley and maize. 2017. 63(6): p. 817-826.

137. Dubey, A. and D.R. Mailapalli, Nanofertilisers, nanopesticides, nanosensors of pest and nanotoxicity in agriculture, in Sustainable agriculture reviews. 2016, Springer. p. 307-330.

138. Shojaei, T.R., et al., Applications of nanotechnology and carbon nanoparticles in agriculture, in Synthesis, Technology and Applications of Carbon Nanomaterials. 2019, Elsevier. p. 247-277.

139. Shalaby, T.A., et al., Nanoparticles, soils, plants and sustainable agriculture, in Nanoscience in Food and Agriculture 1. 2016, Springer. p. 283-312.

140. Gao, J., et al., Polyhydroxy fullerenes (fullerols or fullerenols): beneficial effects on growth and lifespan in diverse biological models. 2011. 6(5): p. e19976.

141. Kole, C., et al., Nanobiotechnology can boost crop production and quality: first evidence from increased plant biomass, fruit yield and phytomedicine content in bitter melon (Momordica charantia). 2013. 13(1): p. 37.

142. YOUSEFZADEH, S. and N.J.A.a.S. Sabaghnia, Nano-iron fertilizer effects on some plant traits of dragonhead (Dracocephalum moldavica L.) under different sowing densities. 2016. 107(2): p. 429-437.

143. Davarpanah, S., et al., Effects of foliar applications of zinc and boron nano-fertilizers on pomegranate (Punica granatum cv. Ardestani) fruit yield and quality. 2016. 210: p. 57-64.

144. Lateef, A., et al., Synthesis and characterization of zeolite based nano-composite: an environment friendly slow release fertilizer. 2016. 232: p. 174-183.

145. Kottegoda, N., et al., A green slow-release fertilizer composition based on urea-modified hydroxyapatite nanoparticles encapsulated wood. 2011: p. 73-78.

146. Zheng, L., et al., Effect of nano-TiO 2 on strength of naturally aged seeds and growth of spinach. 2005. 104(1): p. 83-91.

147. Elfeky, S.A., et al., Effect of magnetite nano-fertilizer on growth and yield of Ocimum basilicum L. 2013. 46(3): p. 1286-1293.

148. Liu, R. and R.J.S.o.t.t.e. Lal, Potentials of engineered nanoparticles as fertilizers for increasing agronomic productions. 2015. 514: p. 131-139.

149. Alexandratos, N. and J. Bruinsma, World agriculture towards 2030/2050: the 2012 revision. 2012. 
150. Ditta, A., M. Arshad, and M. Ibrahim, Nanoparticles in sustainable agricultural crop production: applications and perspectives, in Nanotechnology and plant sciences. 2015, Springer. p. 55-75.

151. Millán, G., et al., Use of clinoptilolite as a carrier for nitrogen fertilizers in soils of the Pampean regions of Argentina. 2008. 35(3): p. 293-302.

152. Liu, R. and R. Lal, Sci Rep. 2014; 4: Article number 5686. DOI.

153. Xiumei, L., et al., Responses of peanut to nano-calcium carbonate. 2005. 11(3): p. 385389.

154. Delfani, M., et al., Some physiological responses of black-eyed pea to iron and magnesium nanofertilizers. 2014. 45(4): p. 530-540.

155. Ghafariyan, M.H., et al., Effects of magnetite nanoparticles on soybean chlorophyll. 2013. 47(18): p. 10645-10652.

156. Ling, D. and B.J.E.P. Xing, Phytotoxicity of nanoparticles: inhibition of seed germination and root elongation. 2007. 150: p. 243-250.

157. Mahajan, Y.J.N.I., Nanotechnology-based solutions for oil spills. 2011. 2(1): p. 1-19.

158. Zhao, L., et al., Influence of $\mathrm{CeO} 2$ and $\mathrm{ZnO}$ nanoparticles on cucumber physiological markers and bioaccumulation of Ce and Zn: a life cycle study. 2013. 61(49): p. 1194511951.

159. Raliya, R. and J.C.J.A.R. Tarafdar, ZnO nanoparticle biosynthesis and its effect on phosphorous-mobilizing enzyme secretion and gum contents in Clusterbean (Cyamopsis tetragonoloba L.). 2013. 2(1): p. 48-57.

160. Taran, N.Y., et al., The effect of colloidal solution of molybdenum nanoparticles on the microbial composition in rhizosphere of Cicer arietinum L. 2014. 9(1): p. 289.

161. Gao, F., et al., Mechanism of nano-anatase TiO 2 on promoting photosynthetic carbon reaction of spinach. 2006. 111(1-3): p. 239-253.

162. Srinivasan, C. and R.J.C.s. Saraswathi, Nano-agriculture-carbon nanotubes enhance tomato seed germination and plant growth. 2010. 99(3): p. 274-275.

163. Parveen, A., B.B.Z. Mazhari, and S. Rao, Impact of bio-nanogold on seed germination and seedling growth in Pennisetum glaucum. Enzyme and Microbial Technology, 2016. 95: p. 107-111.

164. Liu, X., et al., Responses of peanut to Nano-calcium carbonate. Plant Nutrition and Fertitizer Science, 2005. 11(3): p. 385-389.

165. Zhao, L., et al., $\mathrm{CeO}_{2}$ and $\mathrm{ZnO}$ nanoparticles change the nutritional qualities of cucumber (Cucumis sativus). J Agric Food Chem, 2014. 62(13): p. 2752-9.

166. Taha, R.A., et al., Carbon nanotubes impact on date palm in vitro cultures. Plant Cell, Tissue and Organ Culture (PCTOC), 2016. 127(2): p. 525-534.

167. Shah, V. and I. Belozerova, Influence of Metal Nanoparticles on the Soil Microbial Community and Germination of Lettuce Seeds. Water, Air, and Soil Pollution, 2009. 197(1): p. 143-148.

168. Adhikari, T., et al., Growth and enzymatic activity of maize (Zea mays L.) plant: Solution culture test for copper dioxide nano particles. Journal of Plant Nutrition, 2016. 39(1): p. 99-115.

169. Ghafariyan, M.H., et al., Effects of Magnetite Nanoparticles on Soybean Chlorophyll. Environmental Science \& Technology, 2013. 47(18): p. 10645-10652. 
170. Delfani, M., et al., Some Physiological Responses of Black-Eyed Pea to Iron and Magnesium Nanofertilizers. Communications in Soil Science and Plant Analysis, 2014. 45(4): p. 530-540.

171. Pradhan, S., et al., Photochemical Modulation of Biosafe Manganese Nanoparticles on Vigna radiata: A Detailed Molecular, Biochemical, and Biophysical Study. Environmental Science \& Technology, 2013. 47(22): p. 13122-13131.

172. Yuvaraj, M. and K.S. Subramanian, Controlled-release fertilizer of zinc encapsulated by a manganese hollow core shell. Soil Science and Plant Nutrition, 2015. 61(2): p. 319-326.

173. Taran, N., et al., The effect of colloidal solution of molybdenum nanoparticles on the microbial composition in rhizosphere of Cicer arietinum L. Nanoscale research letters, 2014. 9: p. 289.

174. Liu, R. and R. Lal, Synthetic apatite nanoparticles as a phosphorus fertilizer for soybean (Glycine max). Scientific Reports, 2014. 4(1): p. 5686.

175. Zheng, L., et al., Effect of nano-TiO(2) on strength of naturally aged seeds and growth of spinach. Biol Trace Elem Res, 2005. 104(1): p. 83-92.

176. Lin, D. and B. Xing, Root Uptake and Phytotoxicity of ZnO Nanoparticles. Environmental Science \& Technology, 2008. 42(15): p. 5580-5585.

177. Mahajan, P., S.K. Dhoke, and A.S. Khanna, Effect of Nano-ZnO Particle Suspension on Growth of Mung ( $<i>$ Vigna radiata $</ i>$ ) and Gram $(<i>$ Cicer arietinum $</ i>$ ) Seedlings Using Plant Agar Method. Journal of Nanotechnology, 2011. 2011: p. 696535.

178. Agrawal, S. and P.J.I.J.C.M.A.S. Rathore, Nanotechnology pros and cons to agriculture: a review. 2014. 3(3): p. 43-55.

179. Pérez-de-Luque, A. and D.J.P.M.S.f.P.S. Rubiales, Nanotechnology for parasitic plant control. 2009. 65(5): p. 540-545.

180. Nair, R., et al., Nanoparticulate material delivery to plants. 2010. 179(3): p. 154-163.

181. Sathiyamoorthy, R., et al., Biosynthesis of Ag nanoparticles using Ulva fasciata (Delile) ethyl acetate extract and its activity against Xanthomonas campestris pv. Malvacearum. Journal of Biopesticides, 2012. 5: p. 119-128.

182. Ho, V.A., et al., Silver Core-Shell Nanoclusters Exhibiting Strong Growth Inhibition of Plant-Pathogenic Fungi. Journal of Nanomaterials, 2015. 2015: p. 241614.

183. Chhipa, H. and N. Kaushik. Development of nano-bio-pesticide using Iron and Eucalyptus plant extract and their application in pest management. in Conference Proceeding of symposium on recent advances in biotechnology for food and fuel, TERI, New Delhi. 2015.

184. Chookhongkha, N., T. Sopondilok, and S. Photchanachai. Effect of chitosan and chitosan nanoparticles on fungal growth and chilli seed quality. in I International Conference on Postharvest Pest and Disease Management in Exporting Horticultural Crops-PPDM2012 973. 2012.

185. Saharan, V., et al., Synthesis of chitosan based nanoparticles and their in vitro evaluation against phytopathogenic fungi. International Journal of Biological Macromolecules, 2013. 62: p. 677-683.

186. Bramhanwade, K., et al., Fungicidal activity of Cu nanoparticles against Fusarium causing crop diseases. Environmental Chemistry Letters, 2016. 14(2): p. 229-235.

187. Giannousi, K., I. Avramidis, and C. Dendrinou-Samara, Synthesis, characterization and evaluation of copper based nanoparticles as agrochemicals against Phytophthora infestans. RSC Advances, 2013. 3(44): p. 21743-21752. 
188. Mondal, K.K. and C. Mani, Investigation of the antibacterial properties of nanocopper against Xanthomonas axonopodis pv. punicae, the incitant of pomegranate bacterial blight. Annals of Microbiology, 2012. 62(2): p. 889-893.

189. Ocsoy, I., et al., Nanotechnology in Plant Disease Management: DNA-Directed Silver Nanoparticles on Graphene Oxide as an Antibacterial against Xanthomonas perforans. ACS Nano, 2013. 7(10): p. 8972-8980.

190. Park, K.J.P.m.a.w.f.b.u.s.n., Korea Patent Application: WPI ACC NO: 2006489267/200650. 2006.

191. Gajbhiye, M., et al., Fungus-mediated synthesis of silver nanoparticles and their activity against pathogenic fungi in combination with fluconazole. 2009. 5(4): p. 382-386.

192. Sharon, M., A.K. Choudhary, and R.J.J.o.P. Kumar, Nanotechnology in agricultural diseases and food safety. 2010.

193. Gopal, M., et al., Nanotechnology and its application in plant protection. 2011. 2030: p. 224-232.

194. Cioffi, N., et al., Copper nanoparticle/polymer composites with antifungal and bacteriostatic properties. 2005. 17(21): p. 5255-5262.

195. Liu, X.-m., et al., Preparation and Testing of Cementing and Coating NanoSubnanocomposites of Slow/Controlled-Release Fertilizer. Agricultural Sciences in China - AGRIC SCI CHINA, 2006. 5: p. 700-706.

196. Mattos, B. and W. Magalhães, Biogenic nanosilica blended by nanofibrillated cellulose as support for slow-release of tebuconazole. Journal of Nanoparticle Research, 2016. 18.

197. Qian, K., et al., Preparation and characterization of nano-sized calcium carbonate as controlled release pesticide carrier for validamycin against Rhizoctonia solani. Microchimica Acta, 2011. 173(1): p. 51-57.

198. Yearla, S.R. and K. Padmasree, Exploitation of subabul stem lignin as a matrix in controlled release agrochemical nanoformulations: a case study with herbicide diuron. Environmental Science and Pollution Research, 2016. 23(18): p. 18085-18098.

199. Paret, M.L., et al., Photocatalysis: effect of light-activated nanoscale formulations of $\mathrm{TiO}(2)$ on Xanthomonas perforans and control of bacterial spot of tomato. Phytopathology, 2013. 103(3): p. 228-36.

200. Jayaseelan, C., et al., Novel microbial route to synthesize $\mathrm{ZnO}$ nanoparticles using Aeromonas hydrophila and their activity against pathogenic bacteria and fungi. 2012. 90: p. 78-84.

201. He, L., et al., Antifungal activity of zinc oxide nanoparticles against Botrytis cinerea and Penicillium expansum. 2011. 166(3): p. 207-215.

202. Batsmanova, L., et al., Using a colloidal solution of metal nanoparticles as micronutrient fertiliser for cereals. 2013, Sumy State University.

203. Scott, N. and H.J.I.B. Chen, Nanoscale science and engineering for agriculture and food systems. 2013. 9(1): p. 17-18.

204. Khodakovskaya, M.V., et al., Carbon nanotubes as plant growth regulators: effects on tomato growth, reproductive system, and soil microbial community. 2013. 9(1): p. 115123.

205. Larue, C., et al., Accumulation, translocation and impact of TiO2 nanoparticles in wheat (Triticum aestivum spp.): influence of diameter and crystal phase. 2012. 431: p. 197-208.

206. Rico, C.M., et al., Interaction of nanoparticles with edible plants and their possible implications in the food chain. 2011. 59(8): p. 3485-3498. 
207. Corredor, E., et al., Nanoparticle penetration and transport in living pumpkin plants: in situsubcellular identification. BMC plant biology, 2009. 9(1): p. 45.

208. Larue, C., et al., Comparative uptake and impact of TiO2 nanoparticles in wheat and rapeseed. Journal of Toxicology and Environmental Health, Part A, 2012. 75(13-15): p. $722-734$.

209. Sattelmacher, B., The apoplast and its significance for plant mineral nutrition. New Phytologist, 2001. 149(2): p. 167-192.

210. Roberts, A., Plasmodesmata and the control of symplastic transport. Plant Cell Environ. Plant, Cell and Environment, 2003. 26: p. 103-124.

211. Wang, Z., et al., Xylem-and phloem-based transport of $\mathrm{CuO}$ nanoparticles in maize (Zea mays L.). Environmental science \& technology, 2012. 46(8): p. 4434-4441.

212. Etxeberria, E., et al., Fluid phase endocytic uptake of artificial nano-spheres and fluorescent quantum dots by sycamore cultured cells: evidence for the distribution of solutes to different intracellular compartments. Plant signaling \& behavior, 2006. 1(4): p. 196-200.

213. Koo, Y., et al., Fluorescence reports intact quantum dot uptake into roots and translocation to leaves of Arabidopsis thaliana and subsequent ingestion by insect herbivores. Environmental science \& technology, 2015. 49(1): p. 626-632.

214. Servin, A.D., et al., Synchrotron verification of TiO2 accumulation in cucumber fruit: $a$ possible pathway of TiO2 nanoparticle transfer from soil into the food chain. Environmental Science \& Technology, 2013. 47(20): p. 11592-11598.

215. Shen, C.X., et al., Induction of programmed cell death in Arabidopsis and rice by singlewall carbon nanotubes. American Journal of Botany, 2010. 97(10): p. 1602-1609.

216. Hong, J., et al., Foliar applied nanoscale and microscale $\mathrm{CeO} 2$ and $\mathrm{CuO}$ alter cucumber (Cucumis sativus) fruit quality. Science of The Total Environment, 2016. 563: p. 904-911.

217. Valavanidis, A., T. Vlachogianni, and C. Fiotakis, 8-hydroxy-2'-deoxyguanosine (8$O H d G):$ a critical biomarker of oxidative stress and carcinogenesis. Journal of environmental science and health Part C, 2009. 27(2): p. 120-139.

218. Wang, X., et al., Zinc oxide nanoparticles affect biomass accumulation and photosynthesis in Arabidopsis. Frontiers in plant science, 2016. 6: p. 1243.

219. Ghosh, M., M. Bandyopadhyay, and A. Mukherjee, Genotoxicity of titanium dioxide (TiO2) nanoparticles at two trophic levels: plant and human lymphocytes. Chemosphere, 2010. 81(10): p. 1253-1262.

220. Zhu, X., et al., Biosensing approaches for rapid genotoxicity and cytotoxicity assays upon nanomaterial exposure. Small, 2013. 9(9-10): p. 1821-1830.

221. Prasad, R., M. Kumar, and A. Varma, Role of PGPR in Soil Fertility and Plant Health. 2015. p. 247-260.

222. Yasur, J. and P.U. Rani, Environmental effects of nanosilver: impact on castor seed germination, seedling growth, and plant physiology. Environmental Science and Pollution Research, 2013. 20(12): p. 8636-8648.

223. Qi, M., Y. Liu, and T. Li, Nano-TiO 2 improve the photosynthesis of tomato leaves under mild heat stress. Biological trace element research, 2013. 156(1-3): p. 323-328.

224. Tang, Y., et al., Oxidative stress-induced toxicity of $\mathrm{CuO}$ nanoparticles and related toxicogenomic responses in Arabidopsis thaliana. Environmental pollution, 2016. 212: p. 605-614. 
225. Piccinno, F., et al., Industrial production quantities and uses of ten engineered nanomaterials in Europe and the world. Journal of Nanoparticle Research, 2012. 14(9): p. 1109.

226. Johnson, A.C. and B. Park, Predicting contamination by the fuel additive cerium oxide engineered nanoparticles within the United Kingdom and the associated risks. Environmental Toxicology and Chemistry, 2012. 31(11): p. 2582-2587.

227. Nicolodi, M. and C. Gianello, Understanding soil as an open system and fertility as an emergent property of the soil system. Sustainable Agriculture Research, 2014. 4(526-201637873).

228. Kumar, A., et al., A review on positive and negative impacts of nanotechnology in agriculture. International Journal of Environmental Science and Technology, 2019. 16(4): p. 2175-2184.

229. Gottschalk, F. and B. Nowack, The release of engineered nanomaterials to the environment. Journal of Environmental Monitoring, 2011. 13(5): p. 1145-1155.

230. Khan, I., K. Saeed, and I. Khan, Nanoparticles: Properties, applications and toxicities. Arabian journal of chemistry, 2019. 12(7): p. 908-931. 